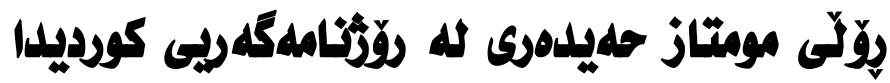

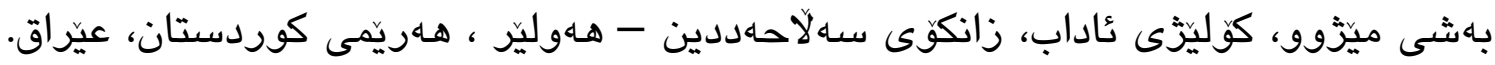
barzan.ali@su.edu.krd

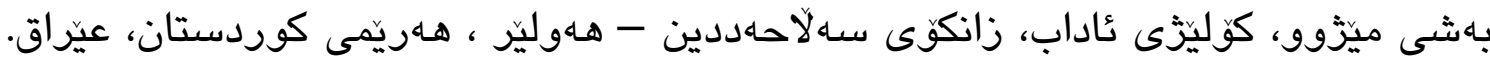
karwan.mohammad@su.edu.krd
بارزان محمد على

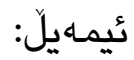

كاروان جوهر محمد كيمـايلّ:

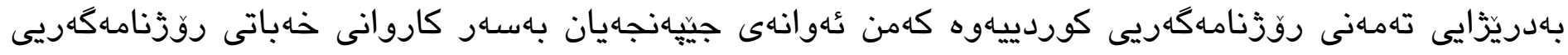

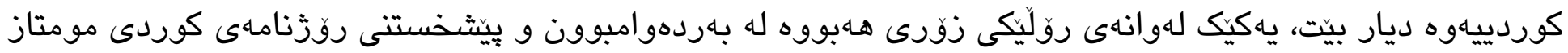

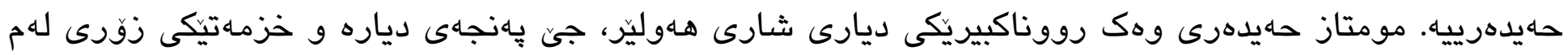

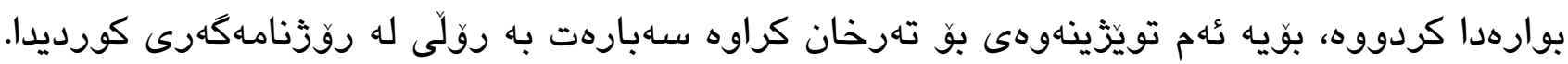

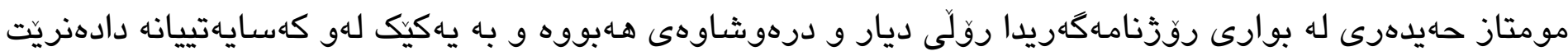

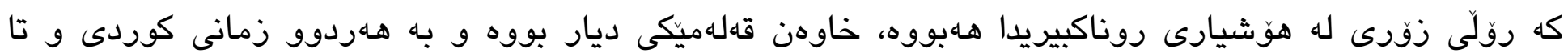

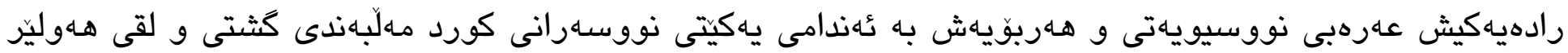

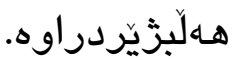

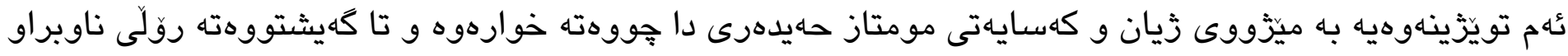

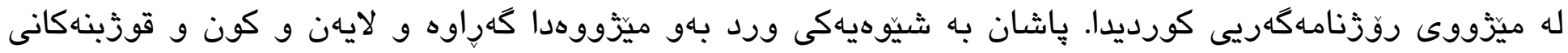

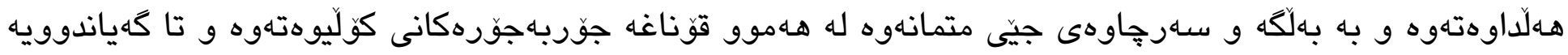

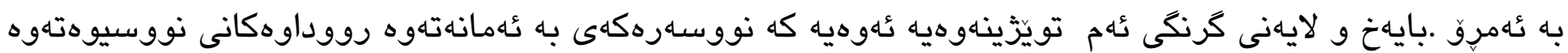

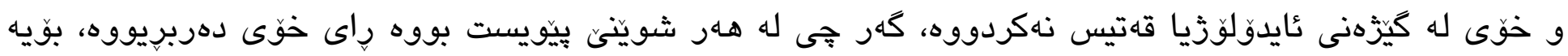

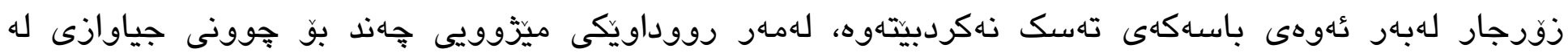

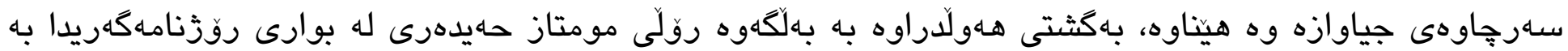

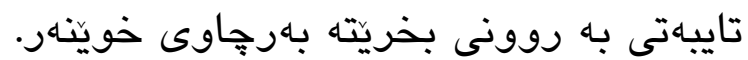

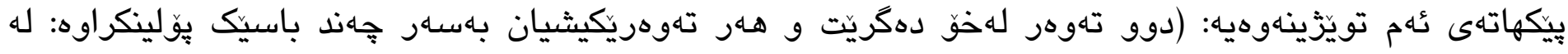

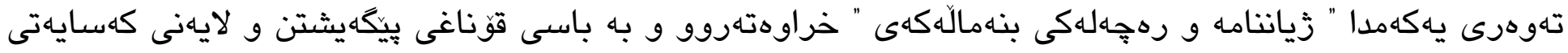




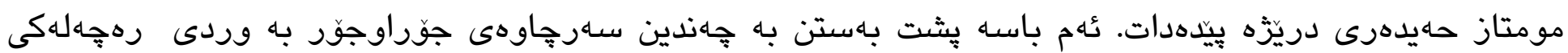

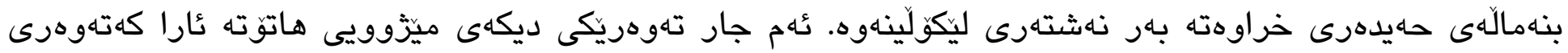

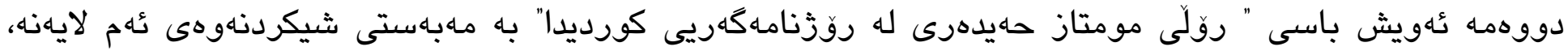

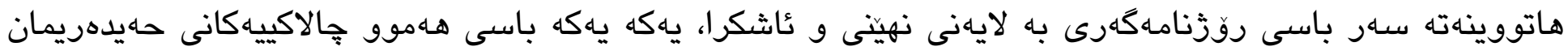

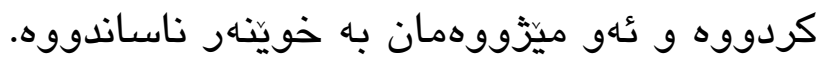

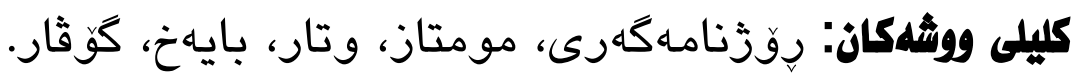

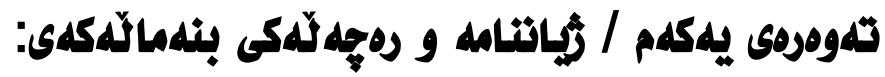

مومتاز كورِى حهيدهر كورى عاصم كورى ئيبراهيم كورى صبغهتولّلاى حهيدهرييه له ريكهوتى (1/8/ 1938)

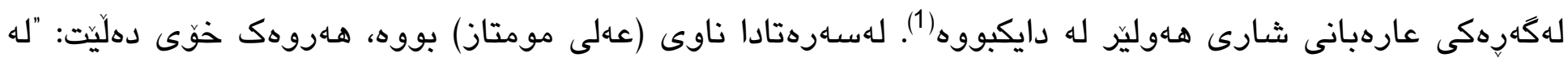
سـاردهمى حكومهاتى مـليك فهيسهل) دا وهزيريّك هـهبوو به ناوى (عهلى مومتاز دهنتهرى)، هـار بوّيه كاتيك له دايك بوومـه له لايهن فاتيمهى يلكييهوه يِيشنار بو بنهمالذكهى كراوه ناوى بنين ( عهلى مومتاز)، ثُهوانيش ناويان ناوم (

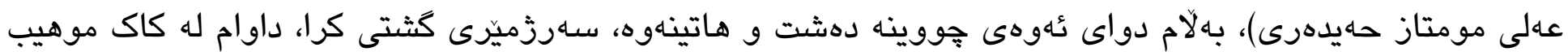
حهيدهرى برام كرد به ناوى (مومتاز) تومار بكريّت، بـم شيّوهيه ناوهكهى كَوراوه بو (مومتاز)" (حهيدهرى، دهستنووس،

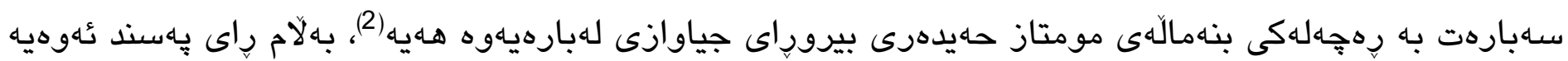

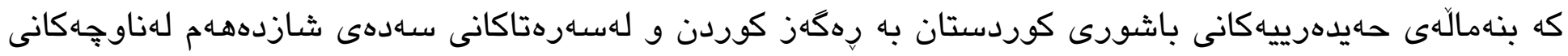

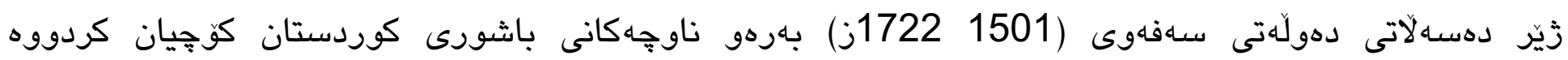

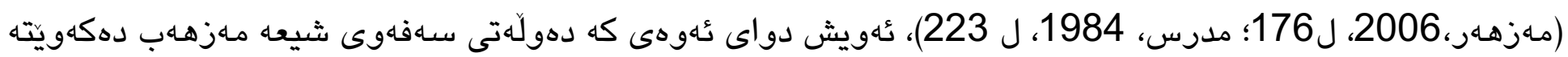

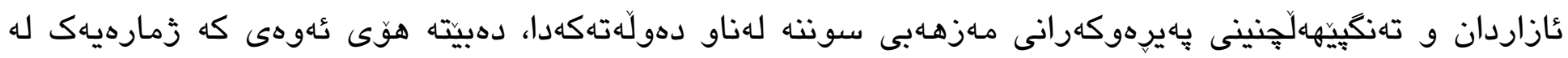

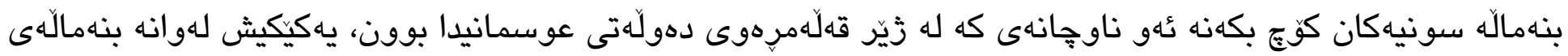
حهيدهرى بوون، دواى هاتنيان بوّناو دهولَهتى عوسمانى، عوسمانيهكان زهوى و زار و جِهند كونديَكيان به مـاهبهتى

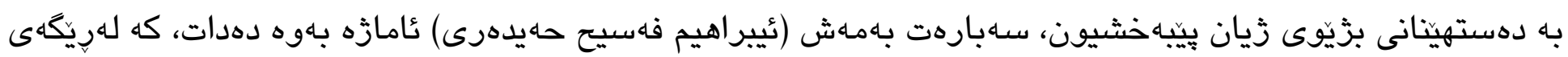
عوسمانييهكانهوه حهيدهرييهكان بوونهته خاوهنى جههندين كوند له ناوجهكانى شـارهزوور و هـهرير (صبخة الله، 1999،

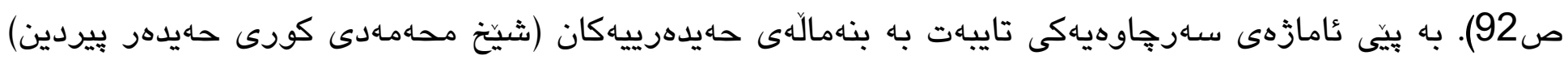
يـكهم كهس بووه، كه للهو بنهمالَهيه كه لهسهرهتاكانى ساهدهى شـازدههاهم رووى كردووهته باشورى كوردستان و 
هـار لهويدّا زيانى هاوسـركيرى يِيكهينّاوهو كوريّكى بووه و ناوى ناوه (حهيدهر)، كه دواتر دهبيته بإييره كهورهى حهيدهرييهكانى كوردستان و عيزراق (الراوي، 2007، ص 128-129).

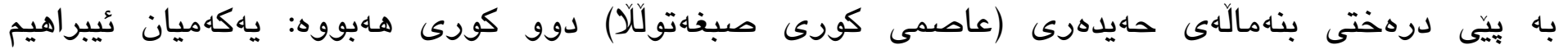
حهيدهرى(1865-1931) له هـهوليَر له دايك بووه و دواى تهواوكردنى قوناغهكانى خويندنى ثايينى له شارى هـهوليّر،

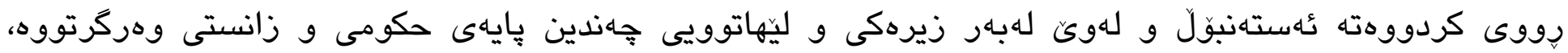
لهديارترينيان سـالى 1906 دهبيته قازى ويلايهتى دياربكر ( اينال، 1980/1/3)، له دواى كهروانهوهثى بوّ عيّراق له سالى 1924 له حكومـهى يـكهمى ياسين هاشمى (1924/8/2- 1925/6/21) دهكريّت به وهزيرى ئهوقاف (الحسني، 1998، ص 245؛ زكي، 2005، ص 66 سكابك.

دووهميان (حاهيدهر حهيدهرى) (1876-1954)، كه دهاته باوكى مومتاز حهيدهرى، كهيكى شارهزابووه له زانسته ئاينيهكاندا، لهتهمهنى كهنجيتيدا رووى كردووهته ئهتهنبوّل و له ريتكَى (ئيبراهيم حهيدهرى) برايهوه، وهكو

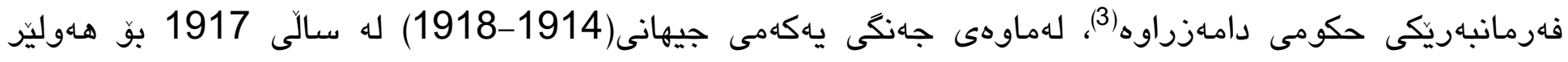

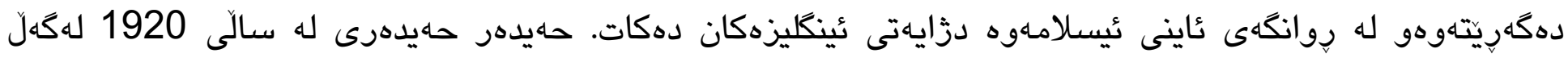

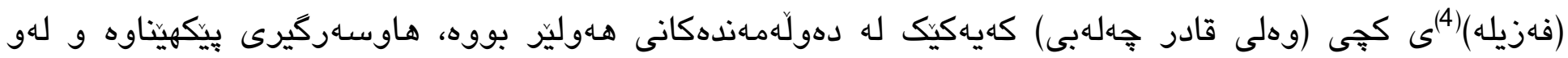
خيزانهى حهوت مندالى هـهووه به ناوهكانى (عاصم، سالح، جهمال،موهيب، مومتاز، جهمشيد، نازهنين) (ديدار للهُّل مومتاز حهيدهرى، له (2015/10/24).

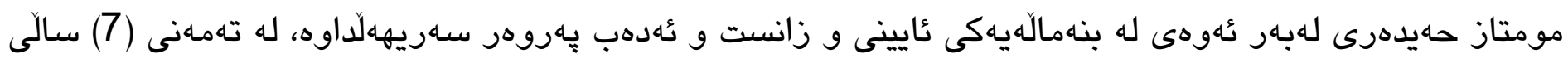

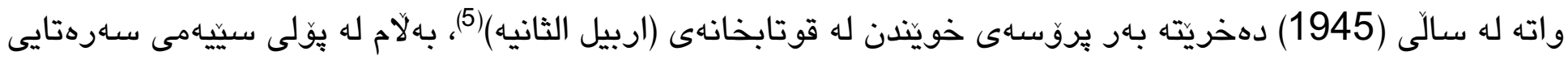
دا بههوى رهوشى زيّده نالهبارى خيزّانهكهيان و بهاندكردنى برا كَورهكانى (عاصد، سالح، جهمال، موهيب) له سالّى

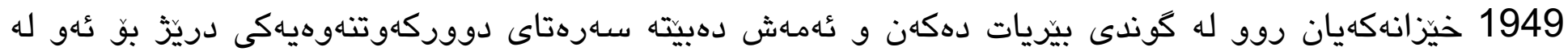
خويندن و قوتابخانه كه ماوهى حهفت سال دهخايهنيت (حهيدهرى، 2011/8/22). بهلاّم كاتيك ( سالح حهيدهرى) براى

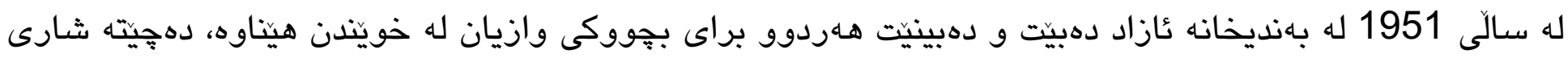

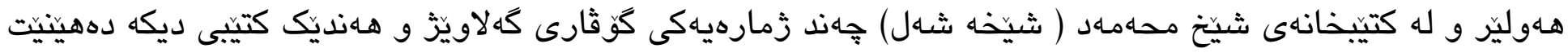

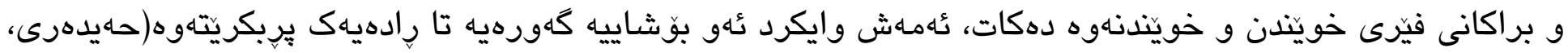

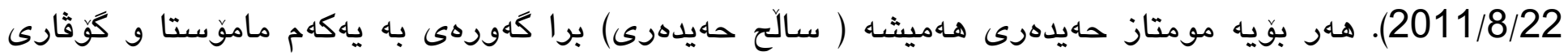
(كَهلاويَّىى) يش به دووهم ماموّستاى خُوى دهزانيّت (حهيدهرى، دهستنووس، ل 31). 


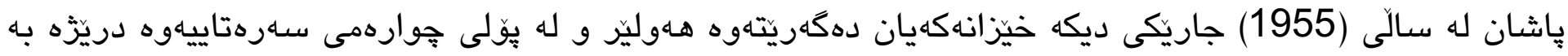

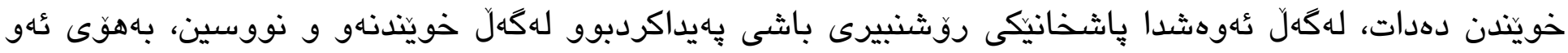

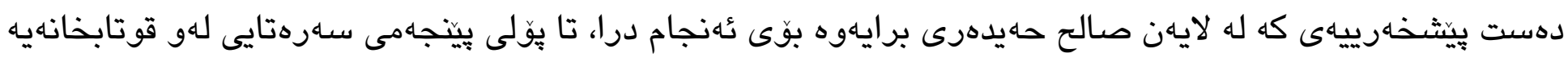

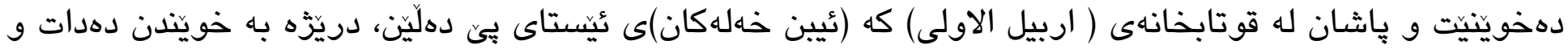
تاوهكو يِّلى سيّيهمى ناوهندى بهردهوام دهبيّ، دواتر به هوَى ئهوهى له 1961/5/1 له لايهن حكومهتهوه دهستكيردهكريّت(6) و رهوانهى خوارووى عيّراق دهكريّت و له تاقيكردنهوهى كوتايى بيّهاش دهكريّي، دووباره له

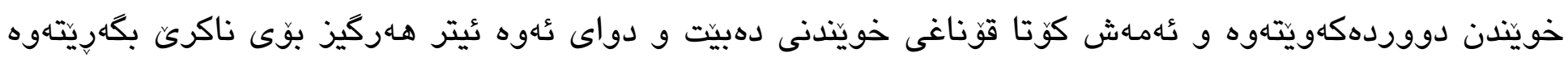
قوتابخانه له شارى هـوليّر (حهيدهرى، 2011/8/22). دواى دهرجوونى له زيندان، به برياريكى حزبى ثيوعى به

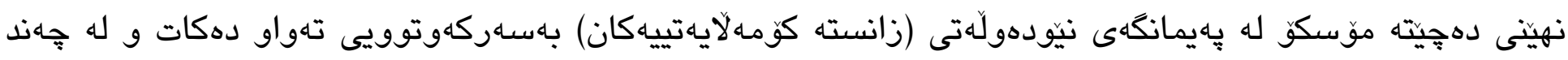
خوليكى كورت خايهنى (يارتيزانى، جايهامـنى، زانستى دهروونى) بهشدارى دهكات ( بابان، 2012، ص 4. 486).

سـاهبارهت به زيانى هاوسهركيرى له سالّى (1971) (رهمزيه)ى كجى سليّمانى كورى محهمهدى كورى سهعيلى

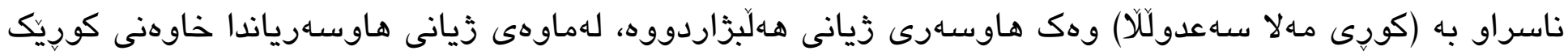

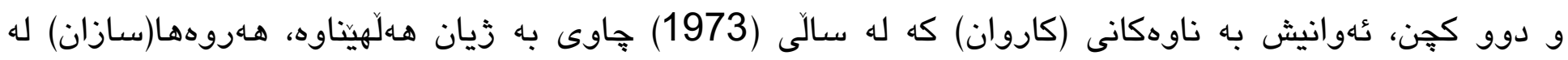
دايكبووى سالّى (1974) و (زيلان) له دايكبووى (1979) (حهيدهرى، 2018، ص 695). 


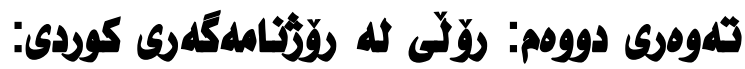

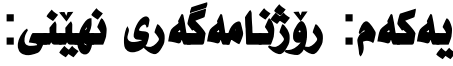

روّزنامهوانى كوردى لهوهتهى سهرى هـلّاوه، بهشيك بووه له بزوتنهوهى نيشتمانييه رزكارييهكهى و زوّر به مكومى پابهندى بووه، بيكومان بارودوخى تايبهتى بزوتنهوهى رزكاريخوازى كورد و سياسهتى داكيركهرانه كاريكيى

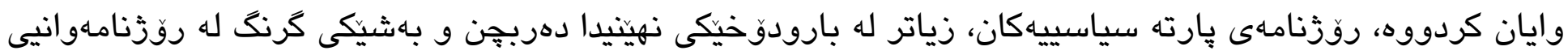

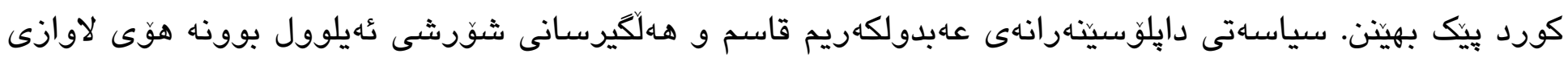

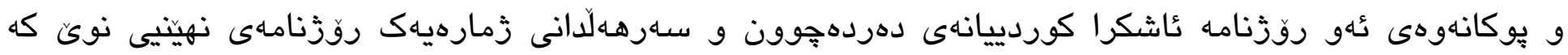

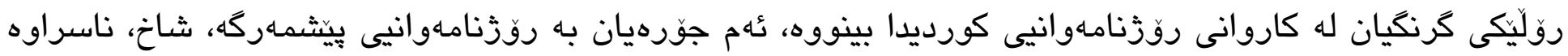

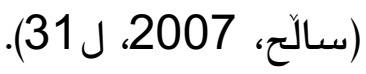

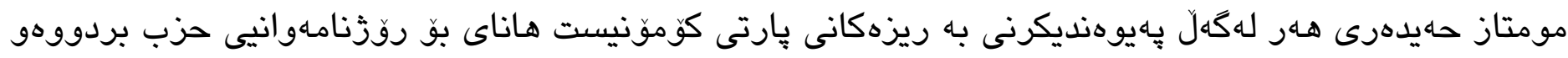

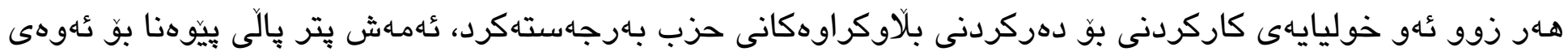

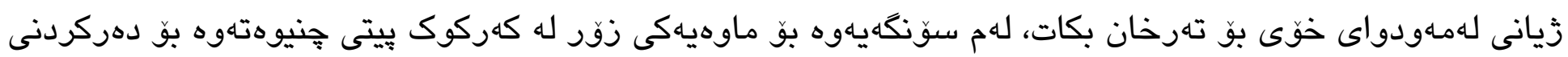
بلاّوكراوهانى حزب و لهم يِيناوهشدا تووشى ئازار و دهربهدهرييهكى زوربووه، لهم بارهيهوه كهريم ئهحمهد

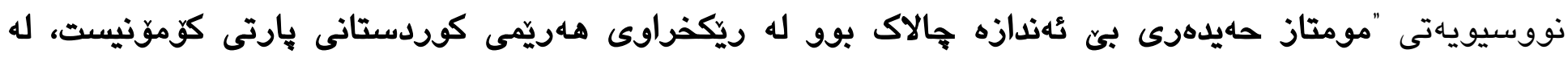

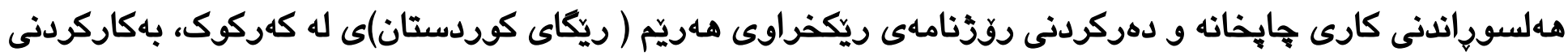

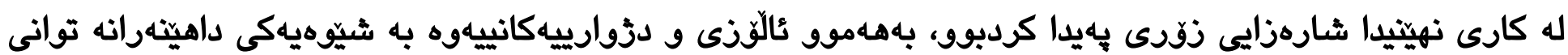

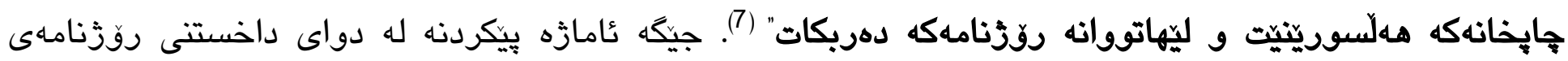

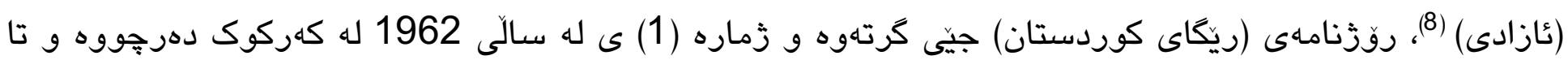

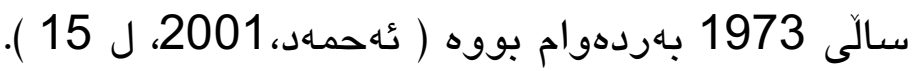

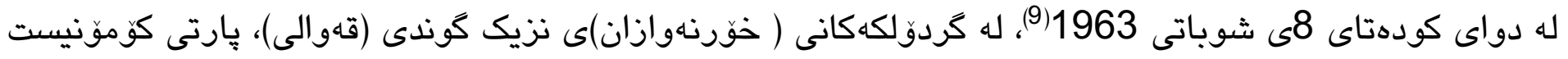

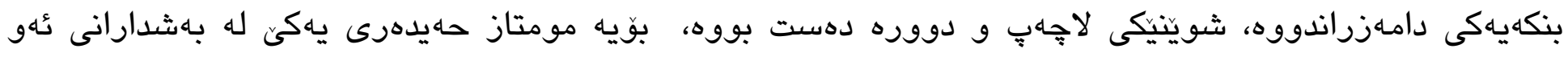

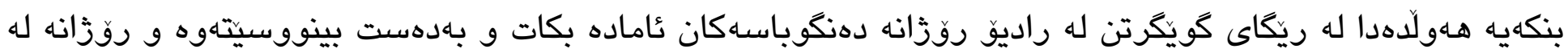

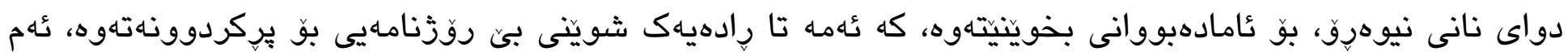

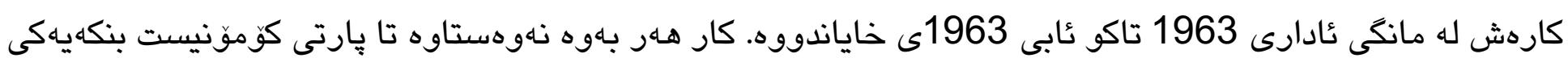




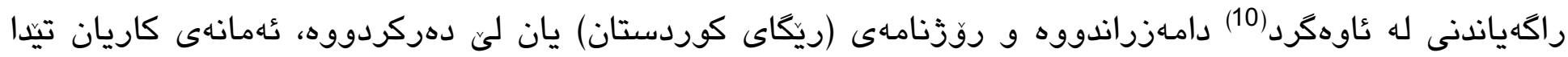
كردووه بريتى بوون له: مومتاز حهيدهرى، محهمهد كهريم فهتحوللا، ئهبو سهامهاد، حوسيّن عارف، عهرهبيكى ناو

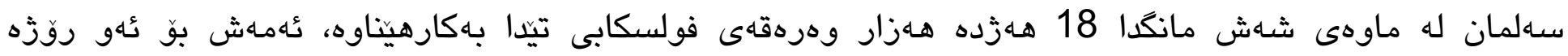
مه غزايهكى زقرىى له بوارى راكهياندن هـيه ( حهيدهرى ، 2018/6/23 )؛ (دهباغ، 2000، ل 58 - 69).

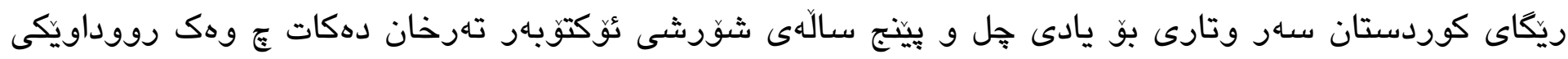
جيهانى و ع عايدولوزَى جيّى بايهخى بووه. له بارهى دوزى كوردهوه نووسيووويهتى " كهلى كورد دوست و دوزمنى

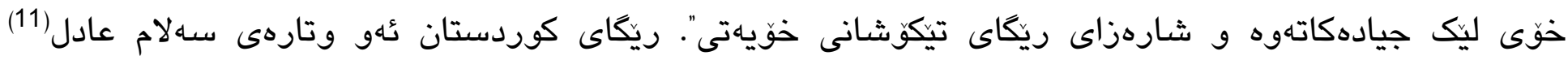

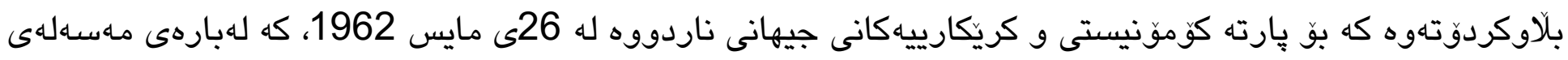
كوردهوه بووه، بهتايبهتيش كوكردنهوهى سويا و توقاندن و پِهلاماردانى كورد و هـلوّيستى حكوماهتى قاسم له ئاست

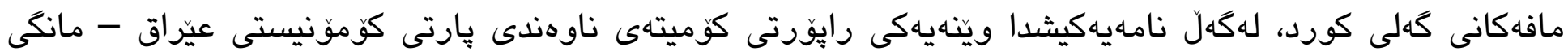

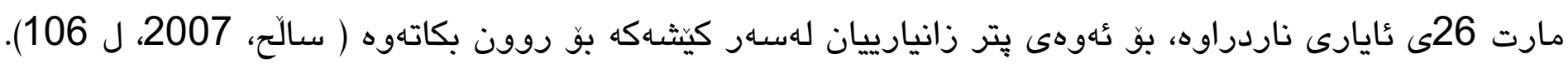

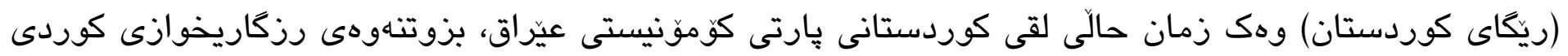

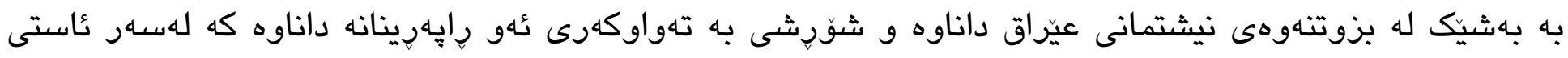

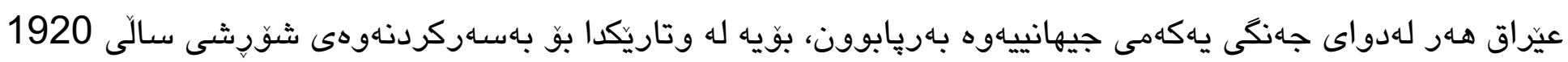
له عيّراقدا ئهم بيرويوّجوونهى خستوّته روو( سالحَ، 2007، ل 107).

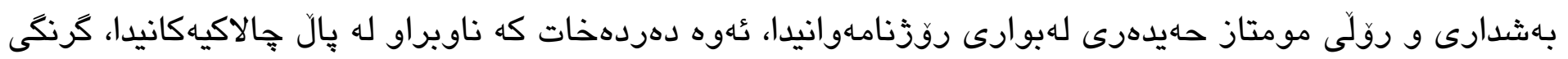

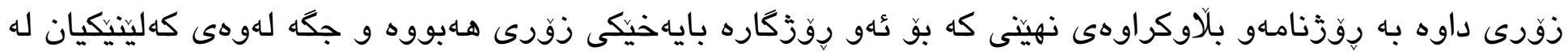

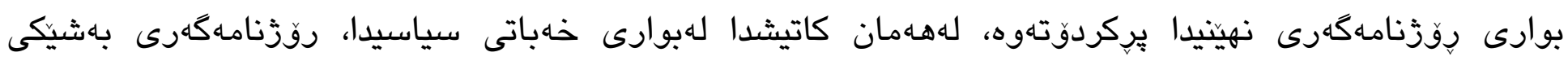

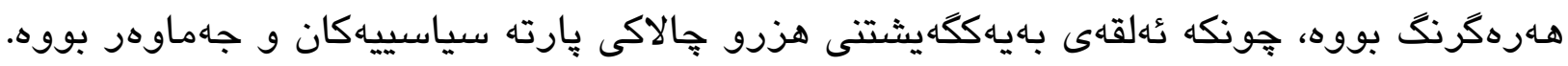




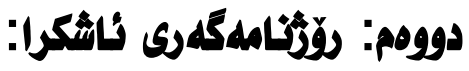

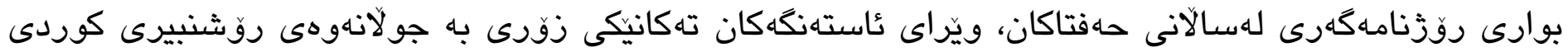

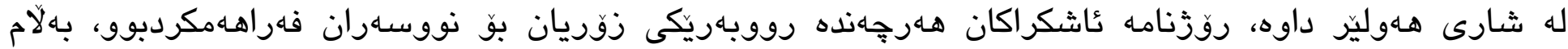

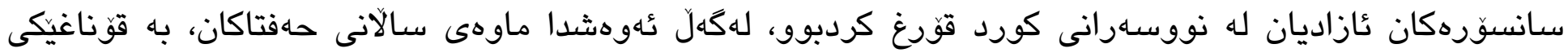

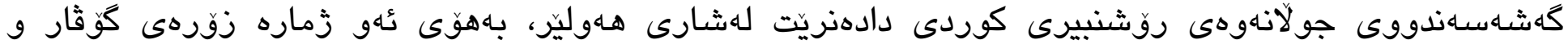
روزنامانهى كه لهشار هـبوونه، بام جوّره ئهدهب و زمان و هونهر و كولتورى كوردى لهبهردهم سياسهاته

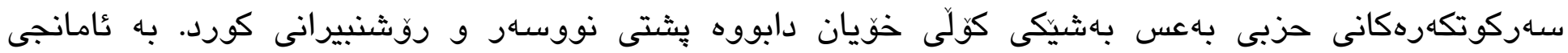

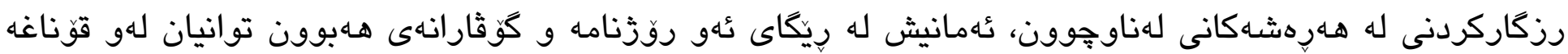

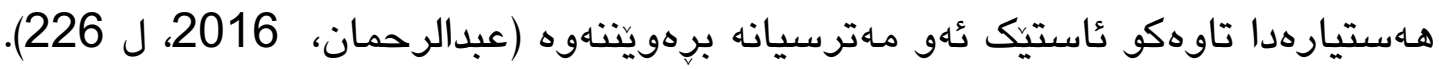

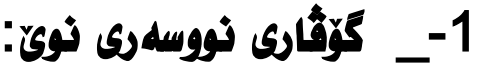

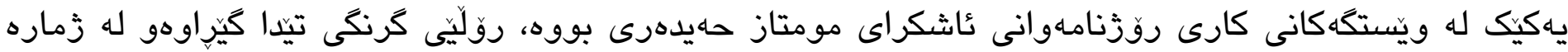

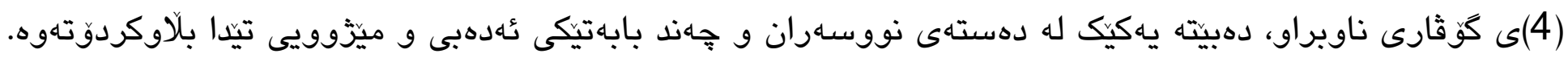

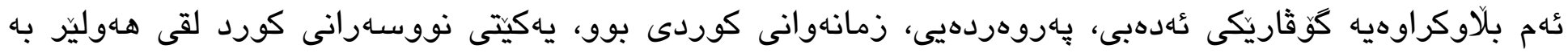

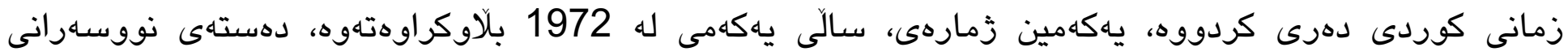

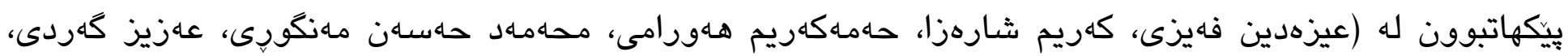

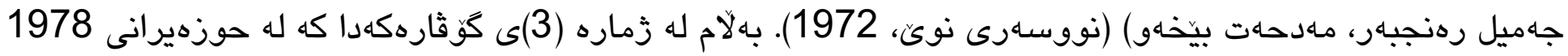

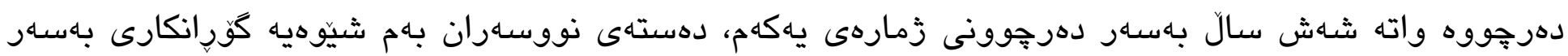

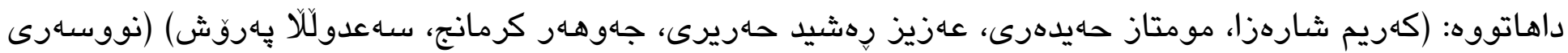

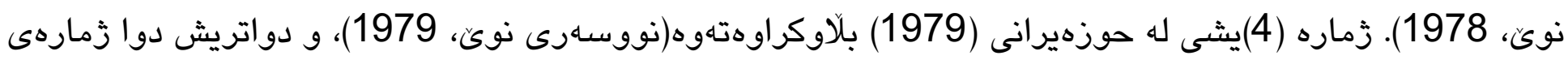

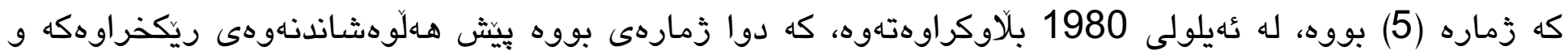

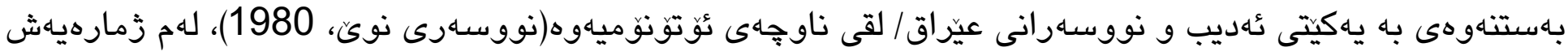

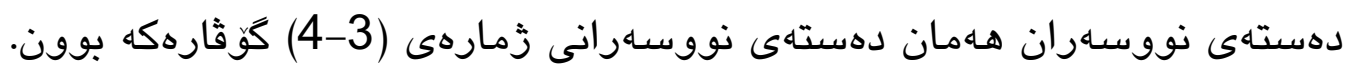

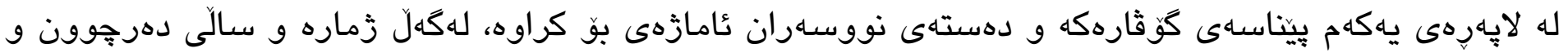

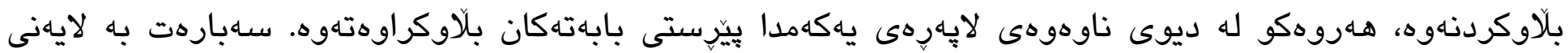

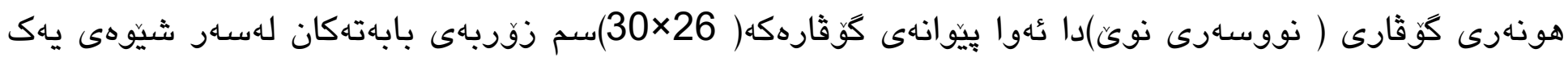

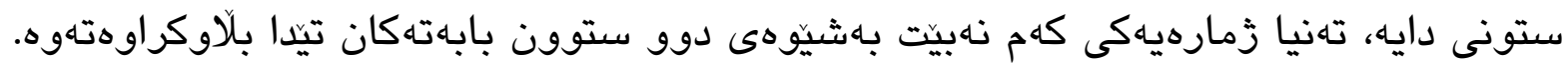




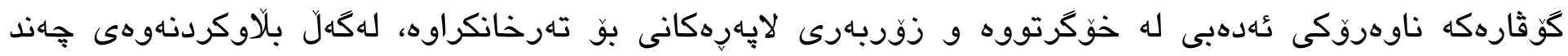

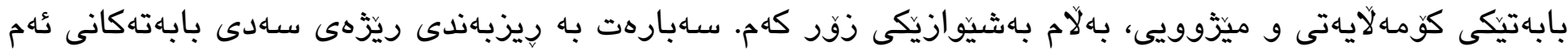

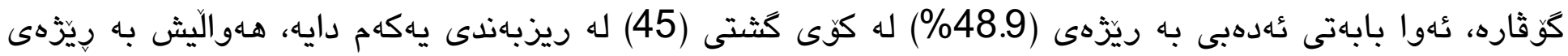

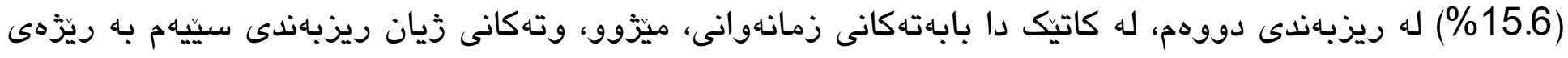

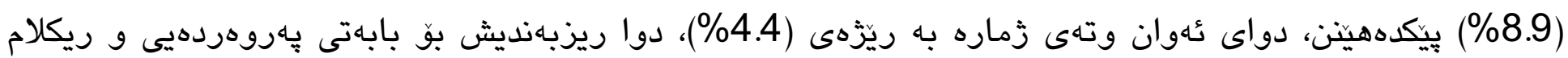
ديّت به ريّزهى (4.4\%) ( سمكو، 2012، ل 238 ).

سـاهبارهت به نووسينهكانى مومتاز حهيدهرى له كَّثارى ناوبراودا، بابهتيكى له زيَّر ناونيشانى(جهواد رهسول

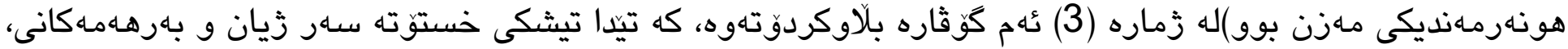
دواتريش جههند تايبهتمـاهدييهكى كهايهاتى ناوبراو شيكردوتهوه، ويّرِاى ئهوهش حهيدهرى كه خُّى يهكيك بووه له قوتابيهكانى به دامـزريناهرى بناغهى جولانهوهى هونهار ناوى دهبات و ئامازّه بوّ ئهوه دهكات كه رووخسارى

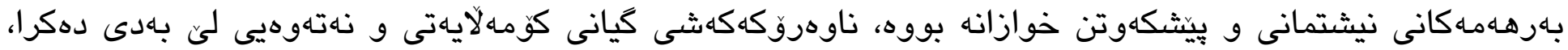

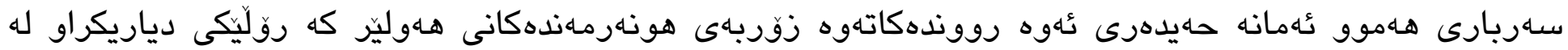

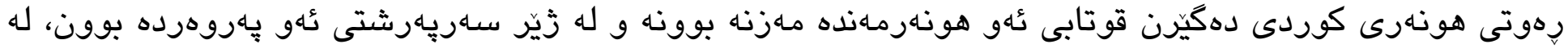
كوتايى نووسينه كهشيدا بو ئهوهى نهوهى داهاتوو زياتر ئاكادارى زيان و بهرهـهمهكانى جهواد رهسول بن، سهـربوردهى ذيانى له جههند خاليّك دا دارشتووه (حهيدهرى، 1978، ل 63-65).

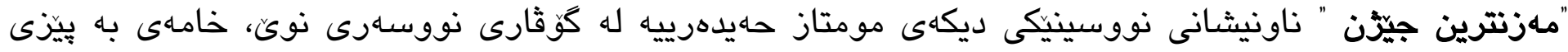

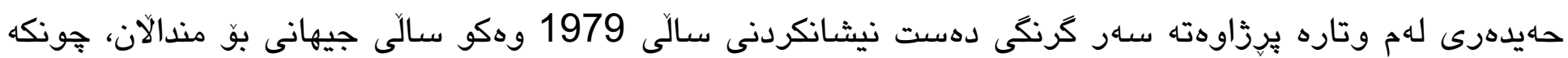

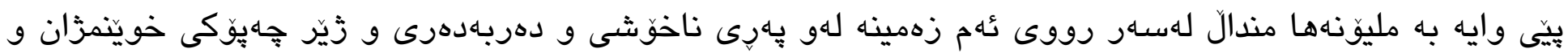

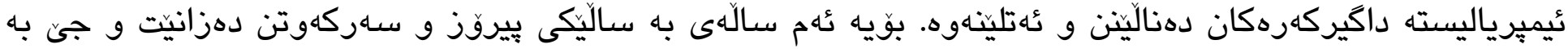

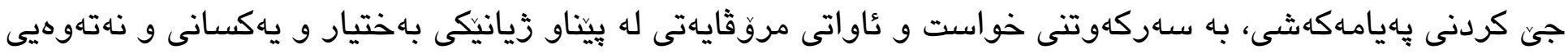

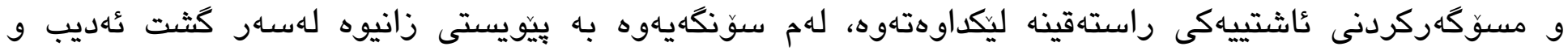

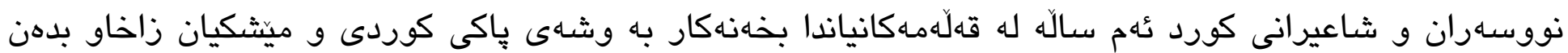
تاكو عازار و عاواتى مندلانى كورد به دلّسوزى له نووسينهكاندا رهنخ بدهنهوه(حهيدهرى، 1978، ل 77-78).

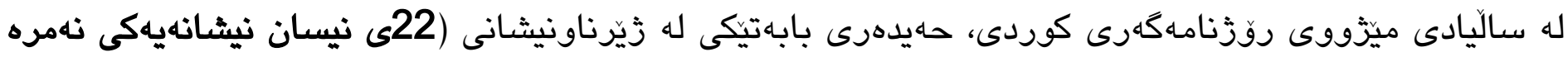

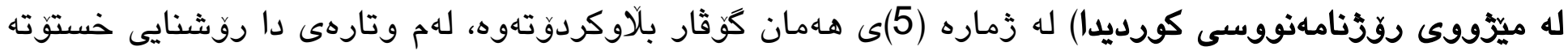

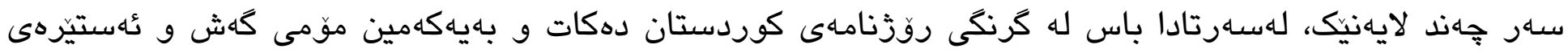

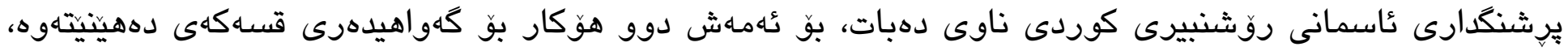
يـكهميان: ترس و لهرزيكى كَهورهى خستوته دلّى دوزمنه خويَن خورهكانى نهتهوهى كورد، دووهميان: زهنكى 


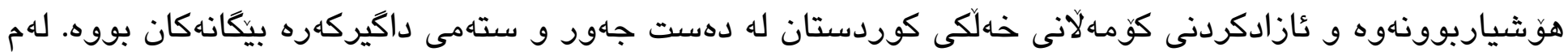

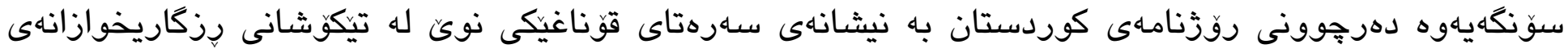
نهتهوهيى و نيشتمانى كومهلانى خهلكّى كوردستان دهزانيت. لهبهشيكى ديكهى وتارهكهى تيشكى خستوته سـهر

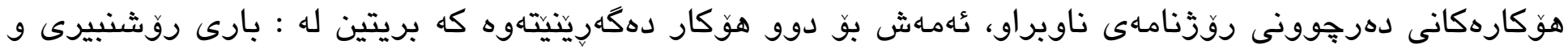
سياسى كورد، عُهويتريان تايبهته به بارو عاستى روشنبيريى و سياسيى جولآنهوهى عازاديخوازانهى كُلانى دراوسيّى كورد ( حهيدهرى ، 1980 ، ل 5-7).

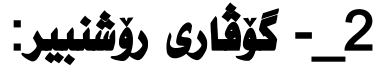

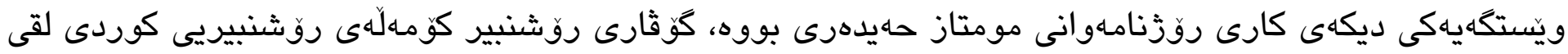
هـوليزّ دهريكردووه، سـرنووسـهى كَّثارهكه (عبدالرزاق بيتوشى)بووه و (ئهحهد شهاريف)يش سكرتيّىى نووسينى بووه، دهستهى نووسـرانى يّيكهاتبوون له (مومتاز حهيدهرى، حازم باجهلان، ساميه شاكر، عبدالقادر حمدامين)

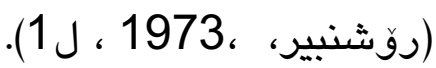

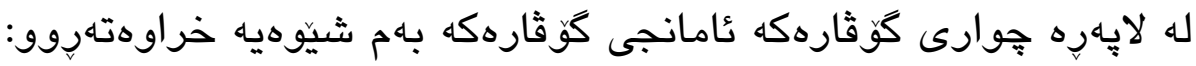

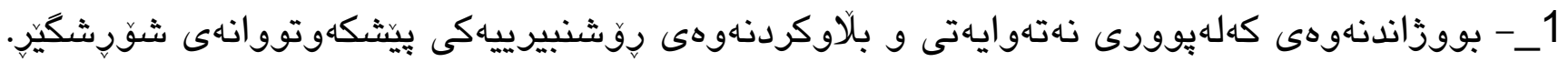

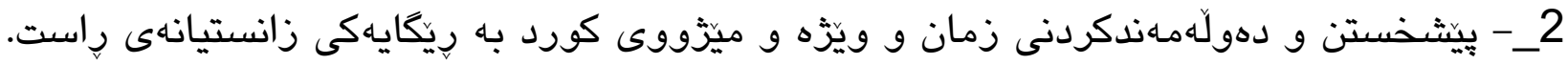

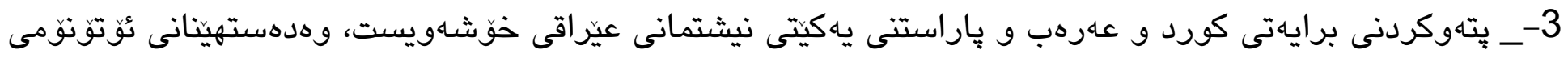
بوّ كوردستان و ديموكراتيهت بوّ عيّراق.

4 - زهمينه خوّشكردن بوّ رِيشه كيش كردنى جِهوساندنهوهى نهتهوايهتى و جِينايهتى. وه بهرزكردنهوهى ئاستى هوَشيارى كومهالآنى خهلكَى كوردستان.

5_- يشتكيريكردنى خهبات و تيكوشـانى كهلانى جيهان له دزى ئيميرياليزم و داكيركهران به تايبهتى كهلى كوردمان و كُهلى فهله ستينى قارهمان ( روّشنبير،1973 ، ل4).

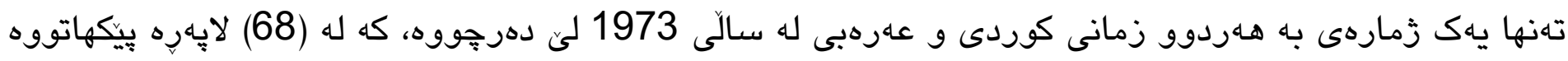

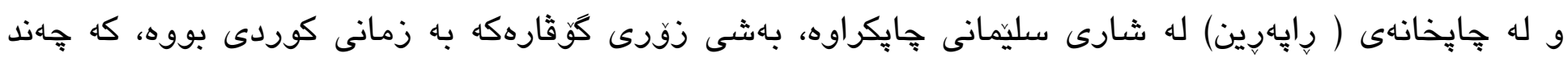




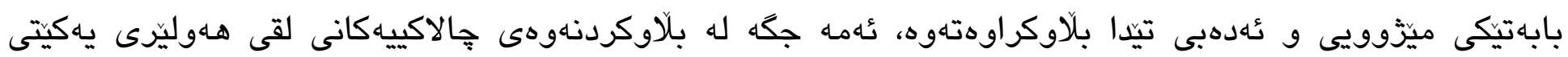
نووسـهرانى كورد(12).

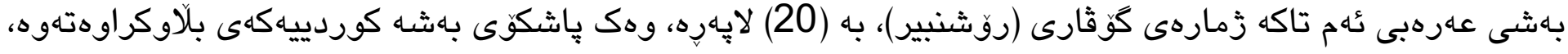

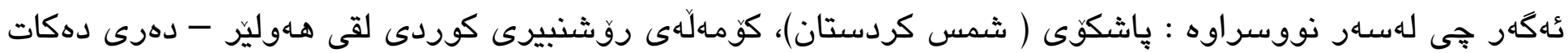

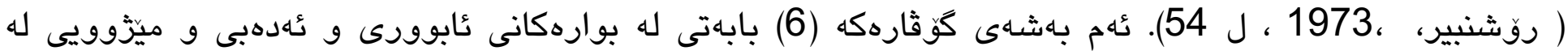
خوَركتووه.

مومتاز حهيدهرى بابهتيكى بـ ناونيشانى ( حاجيى دوشنبيرى شوقرشكيّي) لهم زمارهيهدا بلاوكردوتهوه، لهم

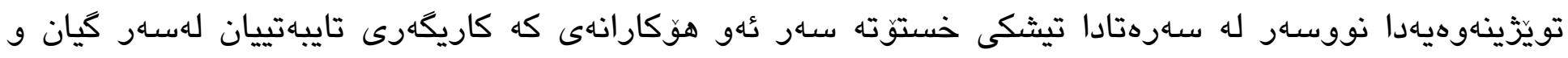

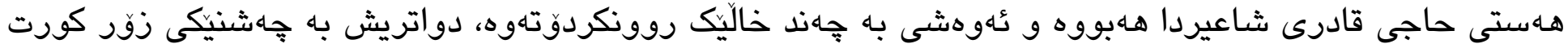

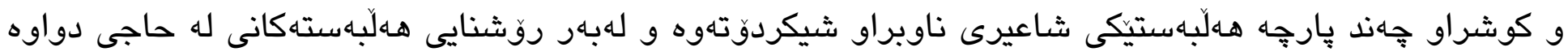
( روشنبير، 1973 ، ل 19-25).

\section{3 _ كُوْارى ثووسهرى كورد:}

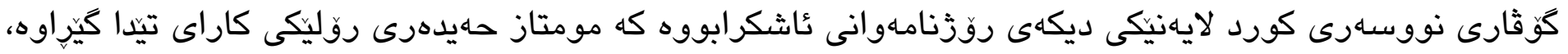

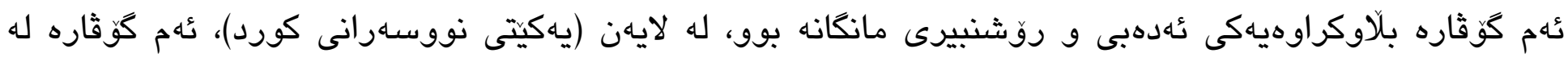
شارى بهغدا بـ زمانى كوردى دهردهجوو. زماره (1)ى خولى يهكهمى له مانكى تادارى 1971، به قهبارهى كتيبيكى

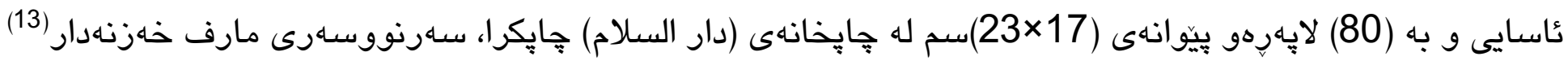
بوو، سكرتيرى نووسين نهسرين فهخرى بوو، لهسهر وتارى زمارهكها هاتووه "كَّثارهكه بيروراى يهكيتى نووسهارانى

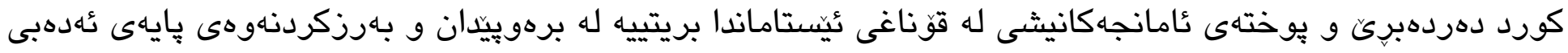
كوردى به هـموو لقهكانييهوه وهكو شعر، وتار، يهخشان، و جيروك، بابهته تازهانى ترى ثئههب ..." (نووسـرى كورد،

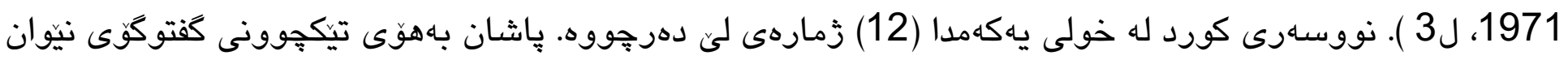

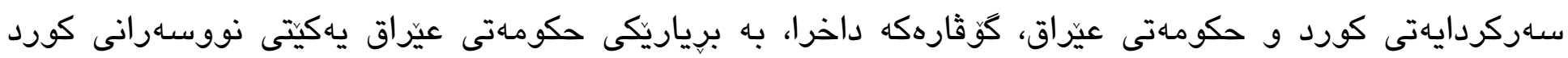

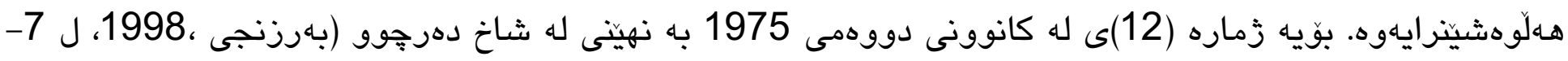

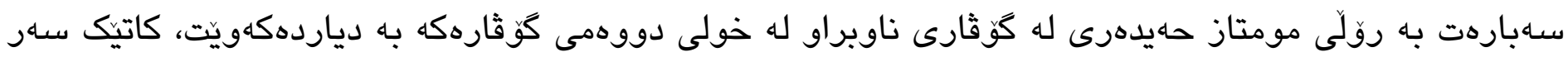

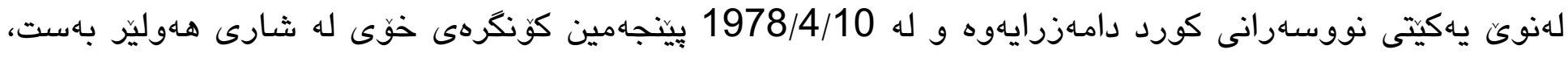


له عايارى 1979 توانى له خولى دووهميدا يهكهمين زمارهى كَّارى (نووسهرى كورد) به قهبارهى (17×17)سم

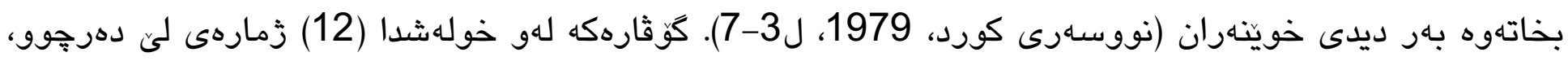

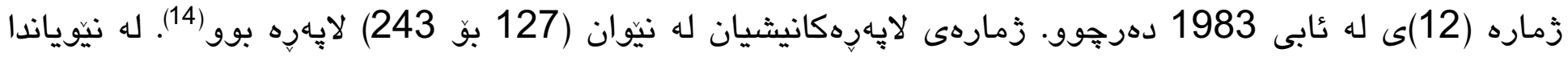

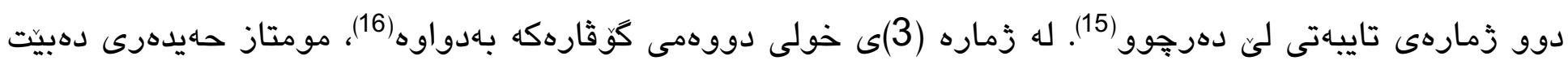

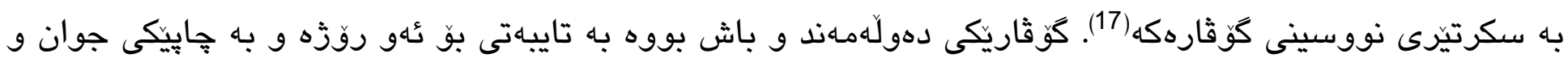

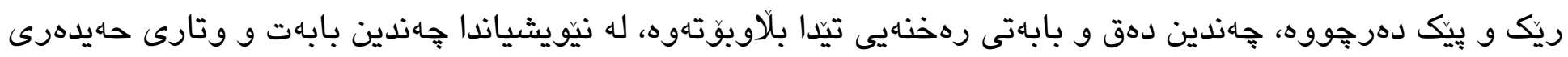

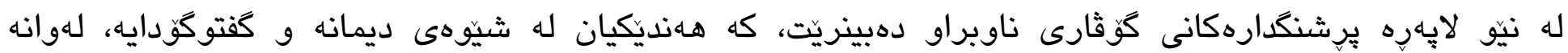

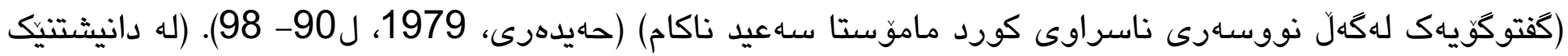

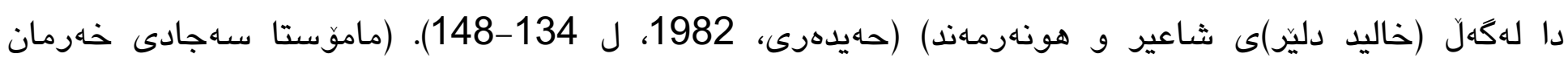
بهرهكهت) (حهيدهرى، 1983، ل 162-165).مومتاز حهيدهرى بابهتيكى له زيّر سـهرديّرى ( لهم مروقه روشنبيره نيشتمانيهروهكانمان : عهبدوللّا عهزيز) نووسيووه(حهيدهرى، 1981، ل 179).لهم نووسينهدا تيشكى خستوته سـهر جهاند لايهنيكى عُهم كهايهتييه كه خويان له ( سـربردهى ذيانى، جالاكى نهتهوهيى و سياسى و روشنبيرى، هـاهتى

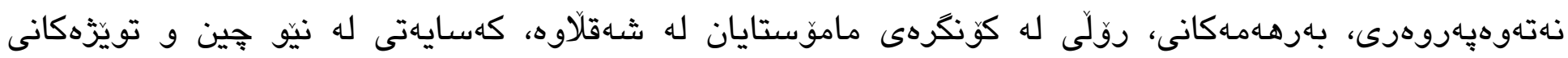

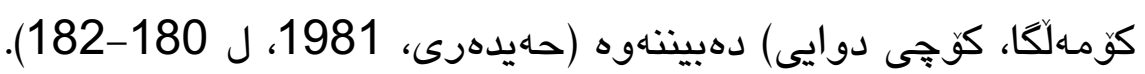

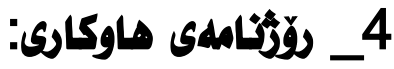

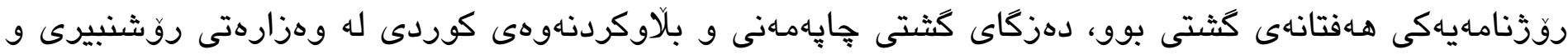

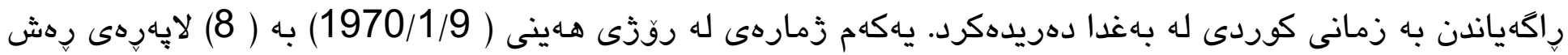

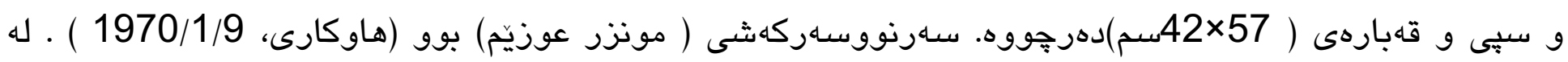
زماره (22)ى سالَى دووهمى (1971/6/26)هوه له (دار الجماهير) دهرجووه و له جايخانهى ( دار الحرية) جايكراوه.

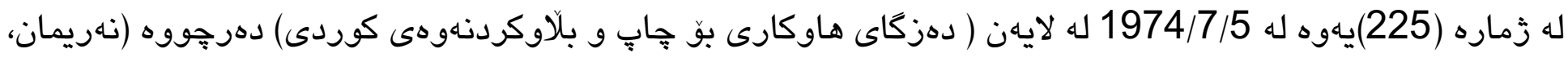
. 1989، ل54)

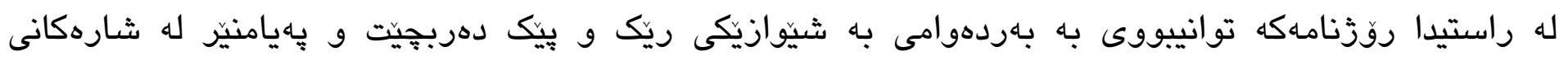

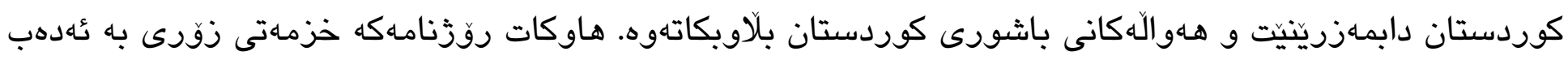




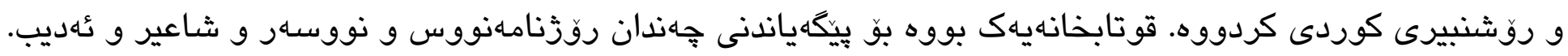

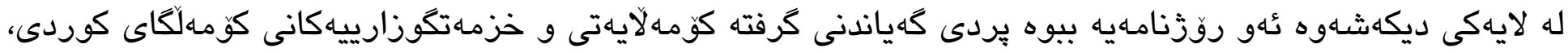

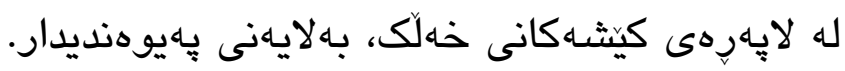

سـابارهت به روّلى مومتاز حهيدهرى له روّزَنامـى ناوبراو، له ريَّكَى ( حهميد عوسمان)(18) له 1/حوزهيرانى 1970

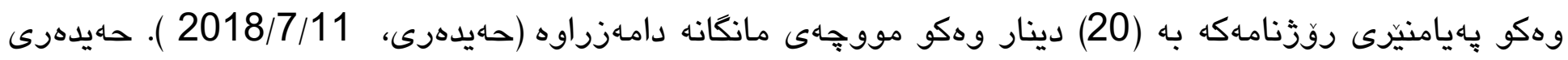

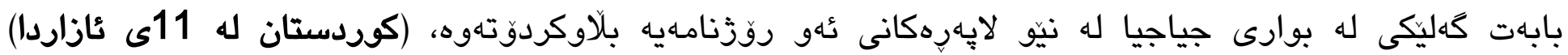

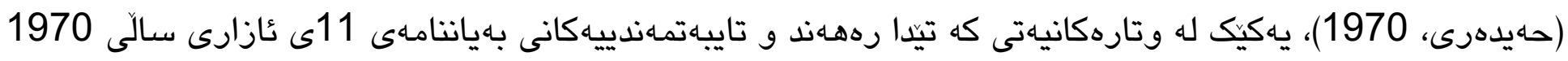

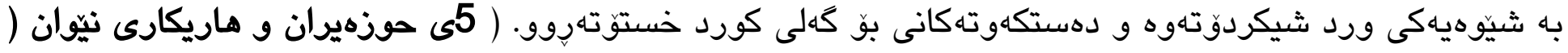

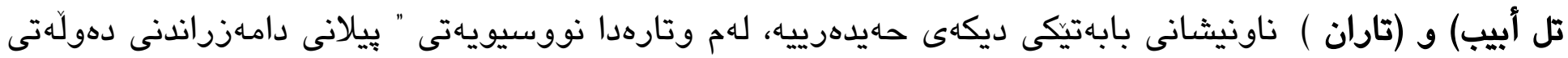

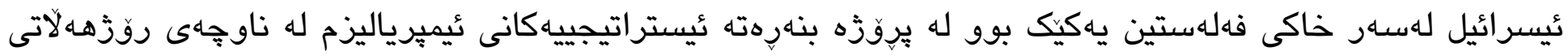

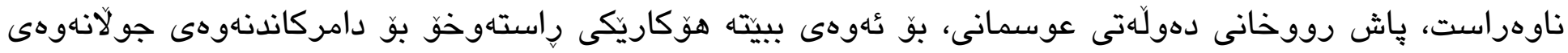

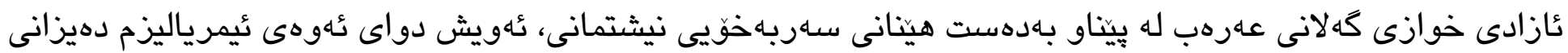

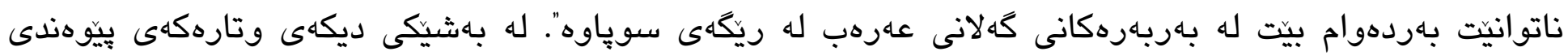

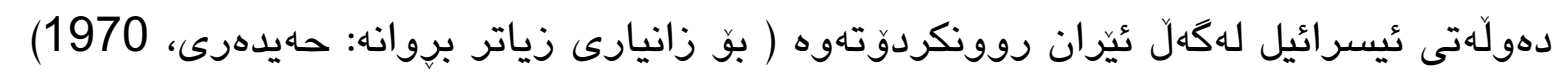

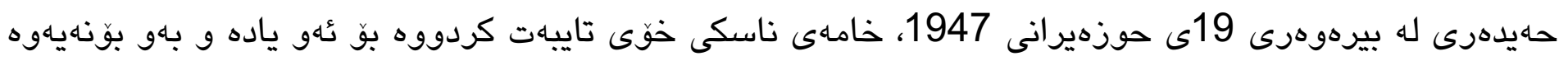
بابهتيكى دوور و دريّزى له زيّر سـهرديّىى ( خوينّى شههيدان ريكاى سهركهوتن تهخت دهكات) نووسيوه و هاوكات

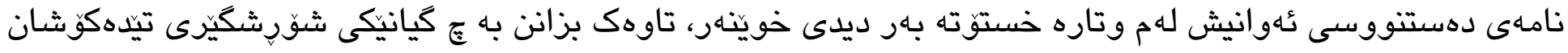
له يِيناوى ثُازادى كَل و نيشتمان (حهيدهرى ، 1970). مومتاز حهيدهرى روّلى كريّكارانى عيّراتى به كورد و عهرهبهوه

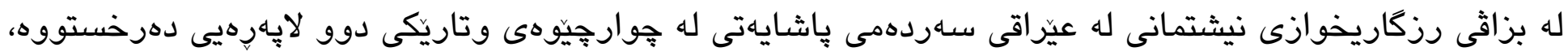

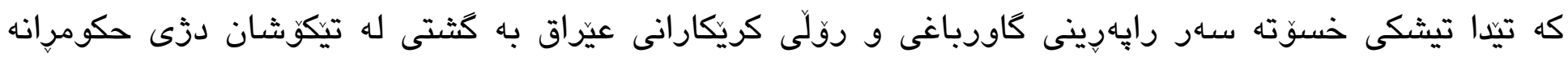

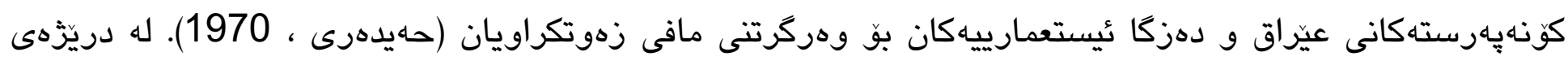
وتارهكانى حهيدهرى، بابهتيكى لهبارهى ميهرهجانى شاعيرى نهتهوهيى حاجى تادرى كويى نووسيوه و تيدا داواى كردووه ئهو ياده بيتيه هاندهريك بو يتهوكردنى ريزهكانى بزوتنهوهى كوردايهتى (حهيدهرى ، 1971). له سوّنكهى

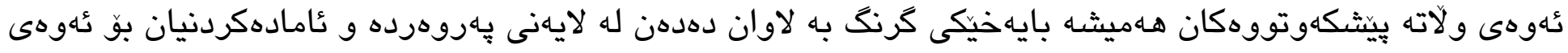

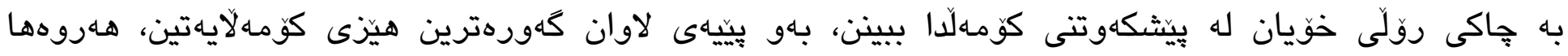

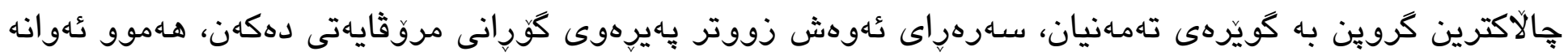

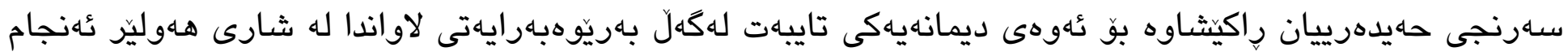
بدات تاوهكو روّلى ئهم بهريّوهبهرايهتيه له كُهـهيّدانى تواناى لاوان بوّ خهلك به ديار بخات (حهيدهرى، 1971). 


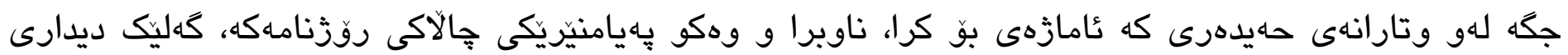

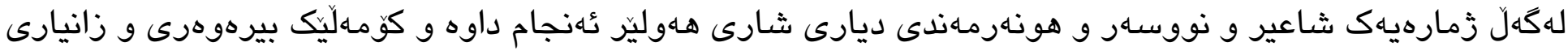

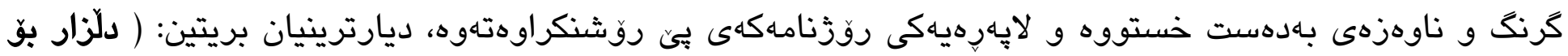
هاوكارى تُدوىكَ) (19)، (ماموستا عهونى حهبيب بيرهوهرى خوّى بوّ هاوكارى باس ئهكا) (20)، ( ديدهنييهكانى قوتابخانهكانى كجانى هـوليّر) (21)، ( 7 يرسيار و نووسهر و روّشنبيرى كوردستان / وهلامى ماموّستا محمد مولود مهم) (22)، ( يهروهردهى هـوليز و شهاش دهوره) (23) ( دانيشتنيك لهكهل ههندى له بهشداربوانى يهكهم كوريى ليكوزلينهوهى كتيبى قوتابخانهك به زمانى كوردى) دا ) (24)، ( كهورهترين فهرههنكى زانيارى عهرهبى / كوردى) (25)، (

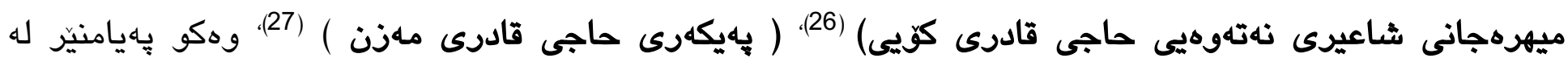

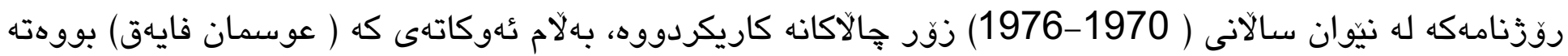
بـاهيرسى روّزنامهكه، به هوَكارى ثُهوهى كه مومتاز حهيدهرى له نووسينهكانى له شوينّى وشهىى (منطقة حكم الذاتي) وشـى (كوردستان)ى بهكار هيناوه، له مانكى 1976/10 له روزنامهكه دهركراوه (حهيدهرى، 2018/7/11).

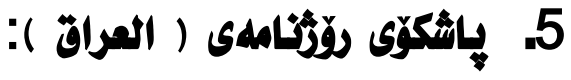

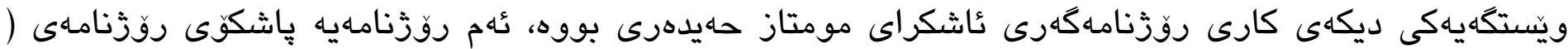

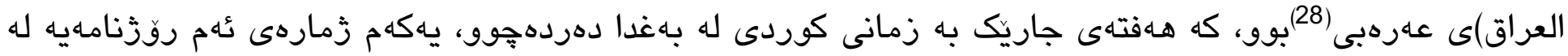

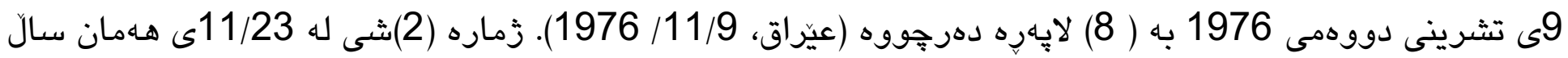

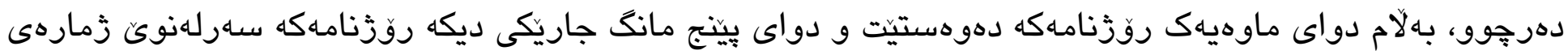

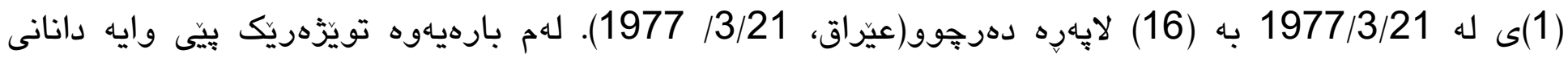

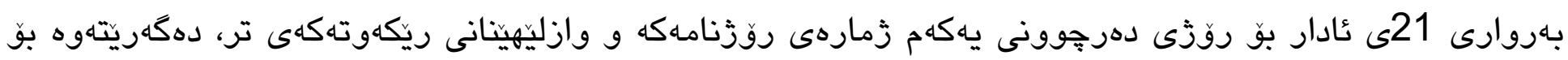


كُهوهى كه ويستوويانه يهكهم زمارهى روّزنامهكه بكهويته يـكهم روزى (نهوروز)هوه كه جهزنيكى نهتهوهيى كورده

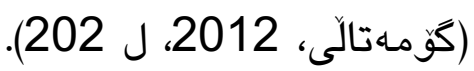

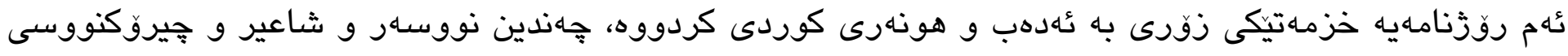
ثُهو كاتى كورد بابهتهكانيان تيّا بلاوكردوتهوه، مومتاز حهيدهريش يهكيك بووه لهوانهى بهرهـهـهانى له زوّربهى

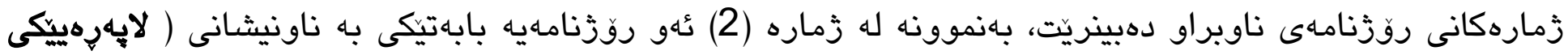

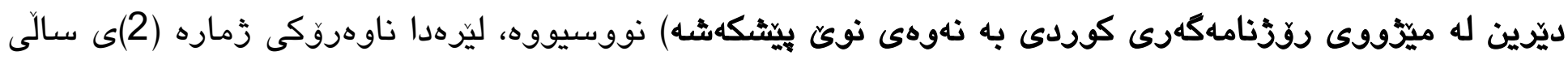

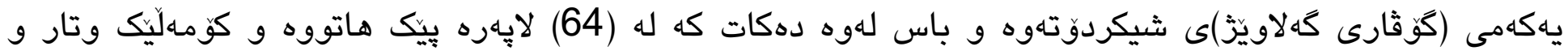

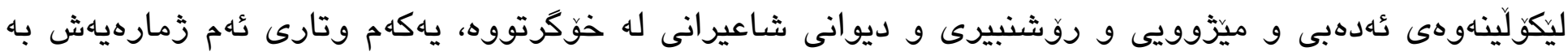

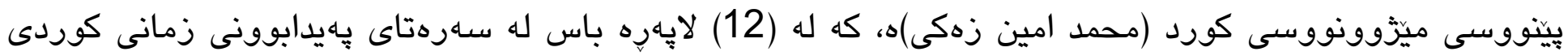
دهكات (حهيدهرى، 1976/11/23).

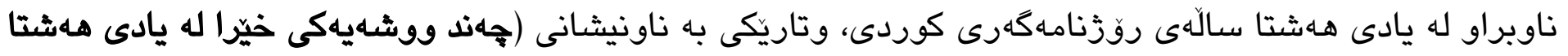

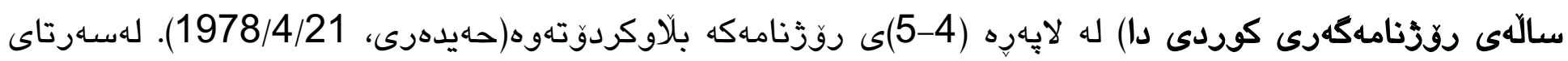

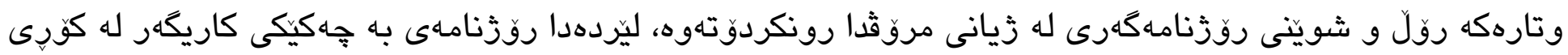

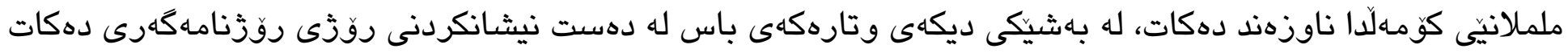
و به نيشانهيهكى خهبات له ميّزووى نهتهوهى كورد دهزانيت، دواتريش له كوَى شهش خالدا باس له دهرجوونى روزّنامهكه دهكات، كه بريتيين له:

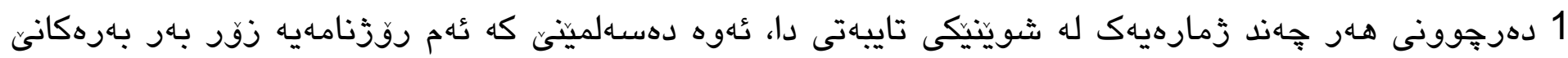
كراوه . 2 روّزنامهى كوردستان خوّى له خوّيدا كه ناوهكهى ( كوردستان) بووه، نيشـانهيهكى نهتهوهييه.

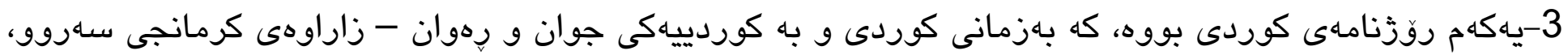

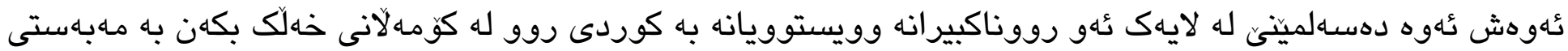

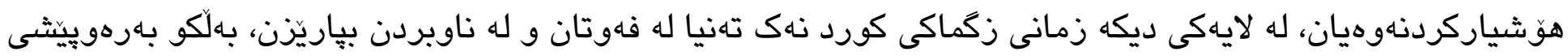
بهن.

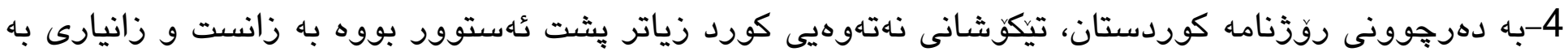

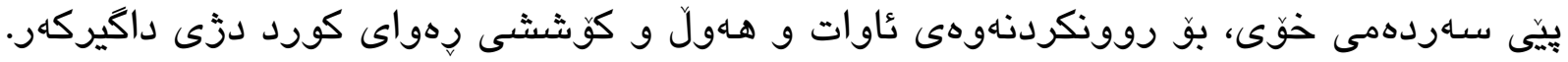

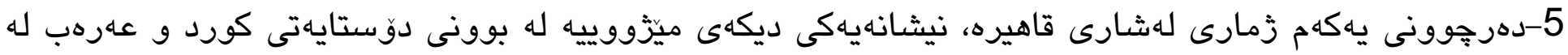
كوريى تيكوّشان و هاوكاريدا.

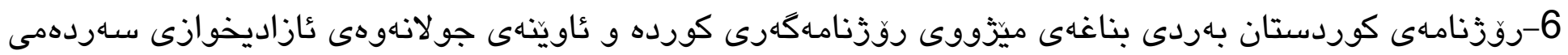
خَى بووه. 


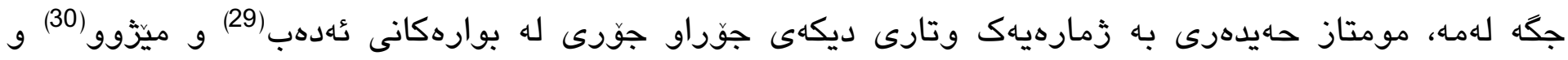

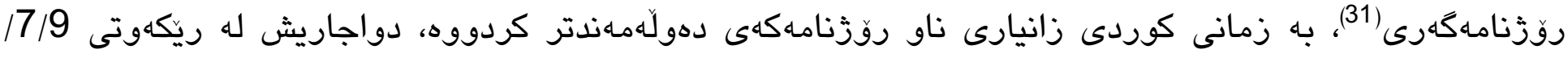

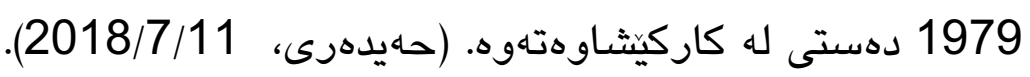

1- رهوشى زيّده نالهبارى خيزّانهكهيان و بـاندكردنى برا كهورهكانى (عاصم، سالح، جهمال،موهيب) له سالّى 1949 وكَهرانهوهى خيزّانهكهيان بو كوند، به يهكيك له هوكاره سـرهكييهكانى دووركهوتنهوهى ئهو له خوينتن و قوتابخانه دادهنريت، له لايهكى ديكهوه، دهستكيركردنى له لايهن حكومـتهوه دوورخستنهوهى بوّ خوارووى عيّراق و بيِبهشكردنى له تاقيكردنهوهى كوتايى،به خاليكى ديكه دادهنريَت لهو هوكارانهى كه بوونهته بهربهاهت لهبهردهم تهواونهكردنى قوَناغه كانى خويندن.

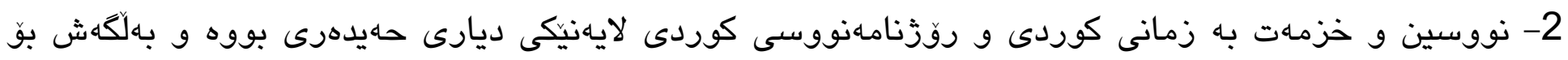

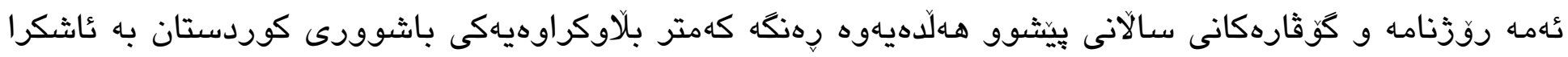
و نهينييهوه دهست كهوكى كه بابهتى به يينيووسى مومتاز حهيدهرى تيدا نهبن.

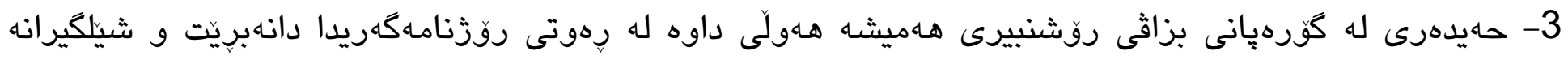

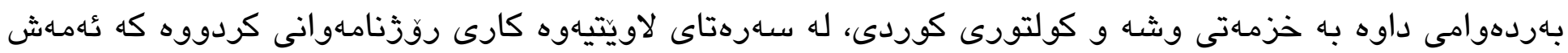

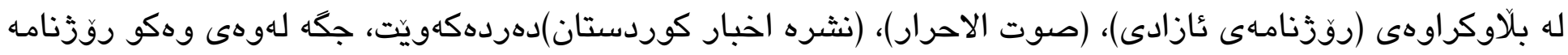

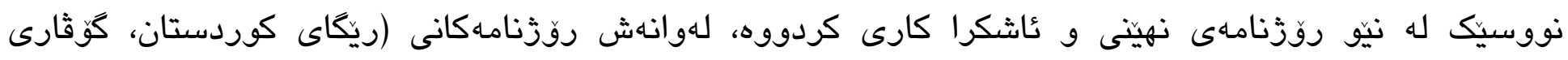

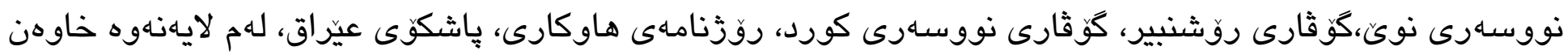

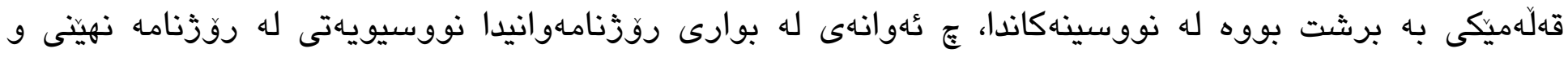
كأثكراكانى كوردى و عهرهبى، ج لهوانهى له بوارى تُهدهبدا نووسيوياهى. 


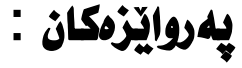

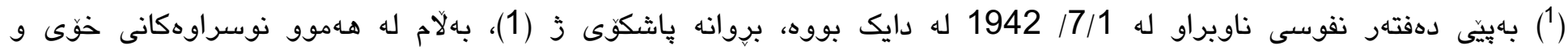

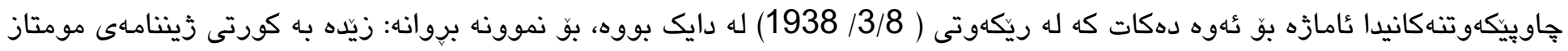

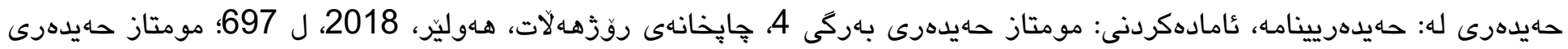

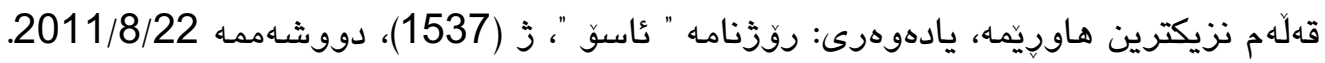

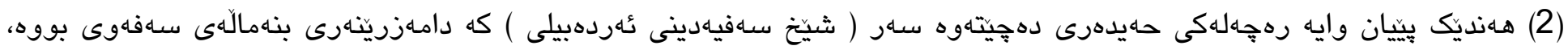

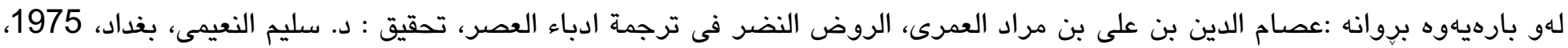

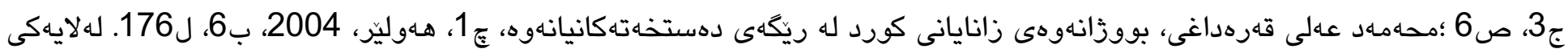

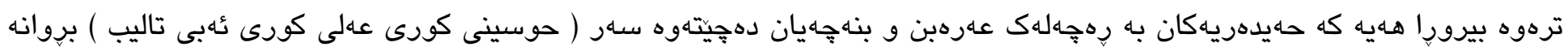

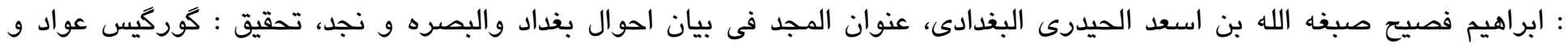

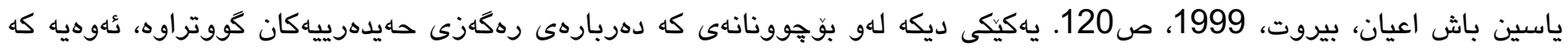

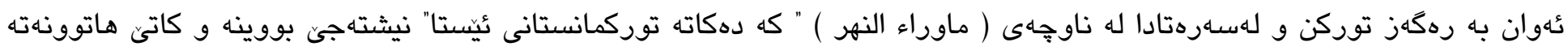

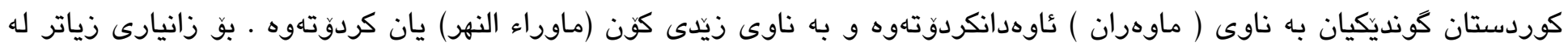

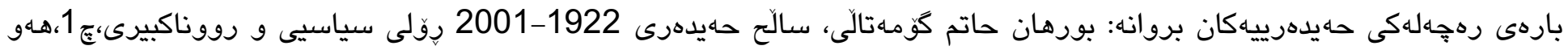

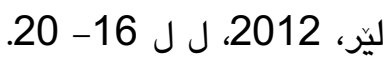
(3) ديدار له كهل جهمشيد حهيدهرى(دكتور)، له (2015/11/26). له سالّى 1943 له هـوليّر له دايك بووه و خويندنى سهردتايى هـهر لهو

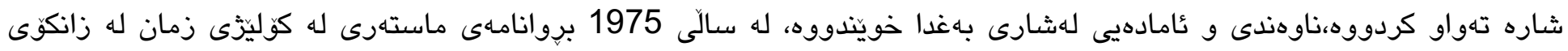

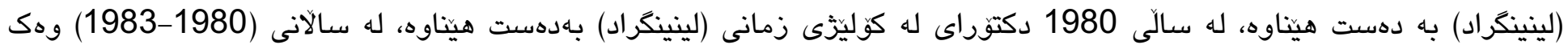

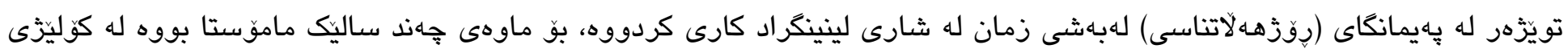

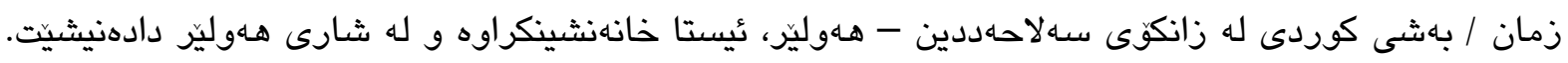

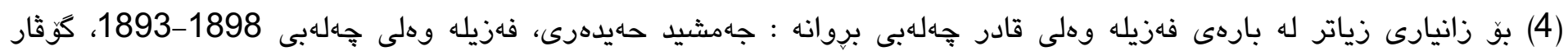

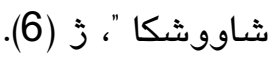

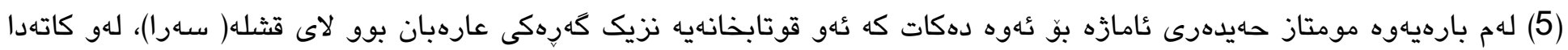

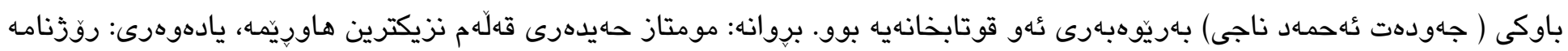

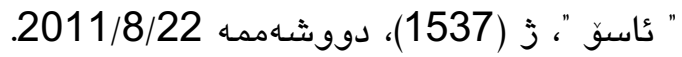

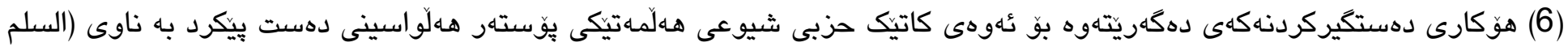

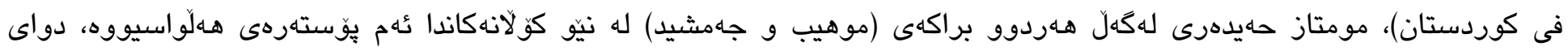
ئهوهى حكومهات ييّى زانيوه و كهوتوته جموجول و دهستكيركردنى ئهو كهسه جالاكانهى ئهو كارهيان دهكرد، مومتاز حهيدهريش يهكيك

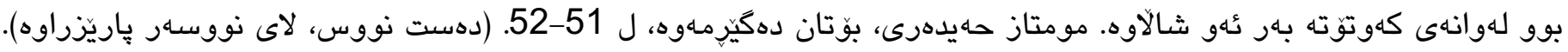
(7) بِِوانه: كريم أحمد، ممتاز الحيدرى، له: حهيدريينامه، بهركى (1)، ل 359.

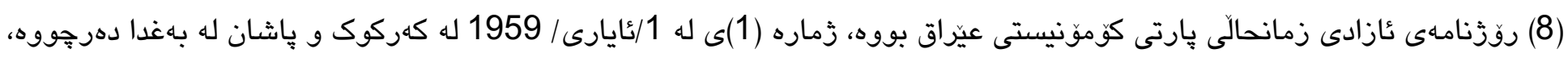

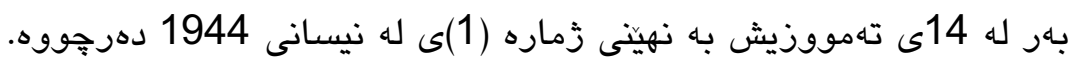

(9) كودهتاى 8ى شوباتى 1963 له ئهنجامى هاوكارى نيوان هـوالخكرى ناوهندى ئهمريكى (CIA) و حزبى بهاعسى عهرهبى ئيشتراكى بوّ رووخانى حكوماتى عبدالكريم قاسم و ليّانى شيوعيهكان سهاركهوت و بو يهكهين جاريش له عيّراق دا حزبى بهعس دهسهالاتى كرته 
دهست، بوّ زانيارى زياتر بروانه: د.على كريم سعيد، عراق 8 شباط 1963 من حوار المفاهيم الى حوار الدم " مراجعات فى ذاكرة طالب

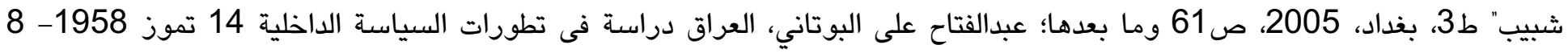

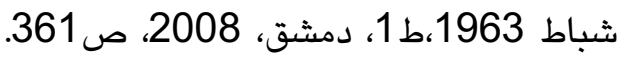

(10) شاخيكه له بشتى كويه، له كوتايى جِياى ( سهاهين)ى بهناوبانگه .

(11) (حسين احمد الرضى ) ناسراو به سهلام عادل له سالّ 1922 له شارى نهجهف له دايك بووه، لهسالّ 1944 جِّوته ريزهكانى

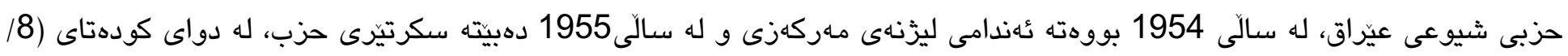

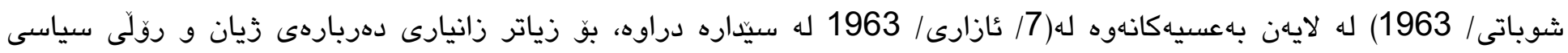

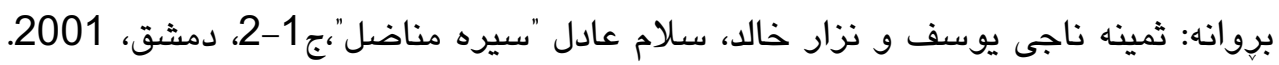

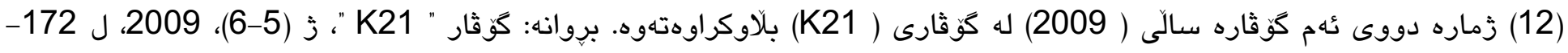

(13)مهاعروف عهبدولقادر عهزيز، ناسراو به مارف خهزنهدار له سالى 1930 له شارى هـوليّر له دايك بووه، سالى 1957 بهشى زمانى

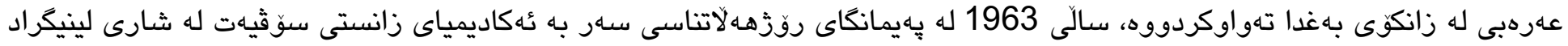

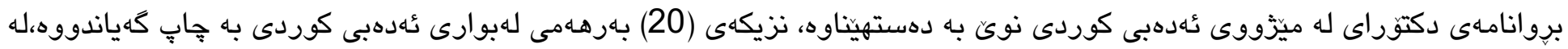

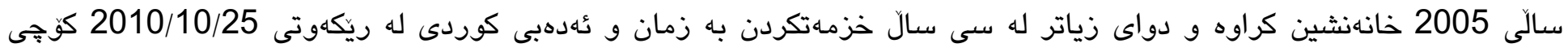

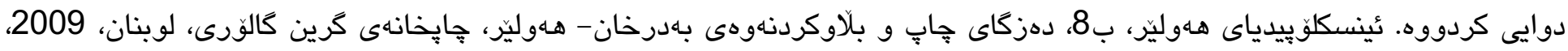

(14) بِروانه: كَّثار " نووسهرى كورد"، ز (1)، خولى دووهم، عايارى 1979، ل 3-7 ؛ تا : زماره (12) خولى دووهم، عابى 1983. (15) ذ (3)، خولى دووهم، مارتى 1980 تايبهت بووه به ئهدهب مندال ؛ ذ (6)، خولى دووهم، شوباتى 1981 تايبهت بووه به رهخنه و لينكولينهاهوه.

(16) له زماره (1-2)ى كَّثارهكه محهمهدى مـهلا كهريم سكرتيّرى نووسين بووه. بروانه: كُوثار " نووسهارى كورد"، ذ (1)، خولى دووهم،

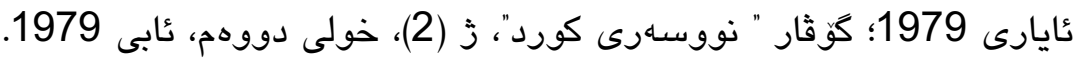

(17) بروانه: كَّثار " نووسـهى كورد"، ذز (3)، خولى دووهم، مارتى 1980 تا زماره (12) خولى دووهم، ئابى 1983.

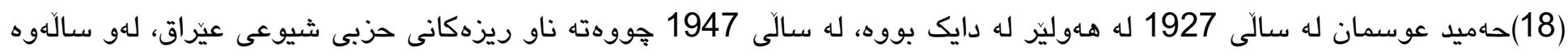
تا 1949 بهريرسى ريكخستنهكانى حزب بووه له سليمانى له حوزهيرانى 1949 دهستكيركراوهو (15) سال حوكم دراوه، له حوزهيرانى 1949

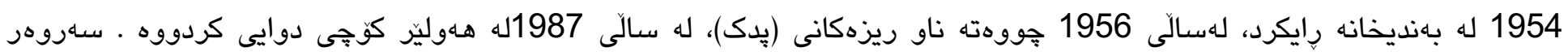

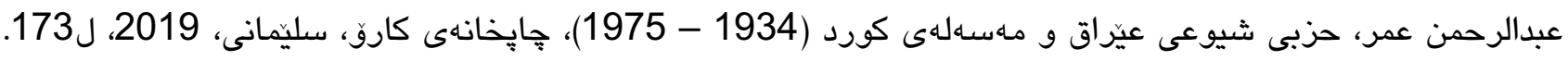

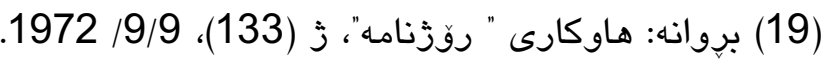

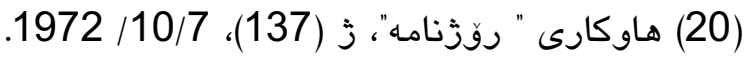

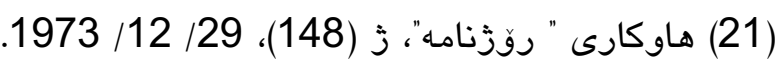

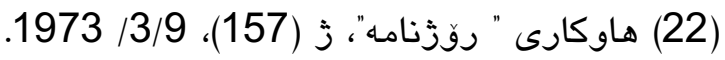




$$
\begin{aligned}
& \text { (23) هاوكارى " روزّنامه"، ذ (174)، 1973/7/6 . }
\end{aligned}
$$

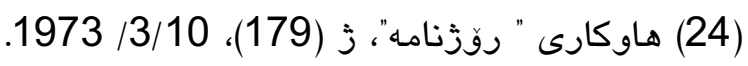

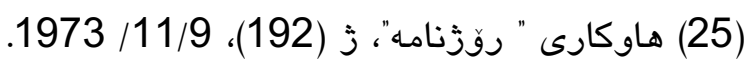

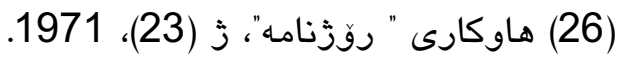

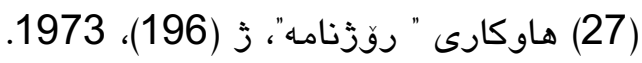

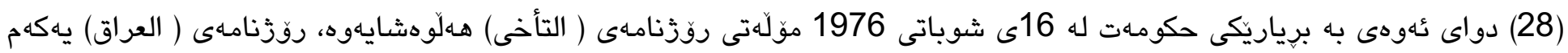

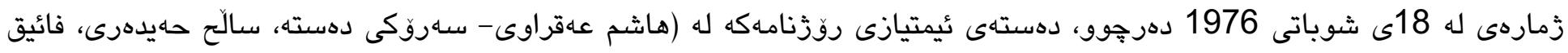

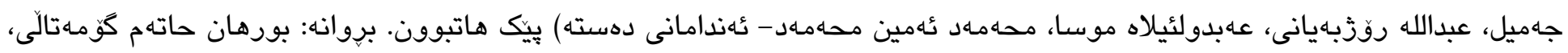
سالح حهيدهرى 1922-2001، هـاوليدر، 2012، 2012، ل 195.

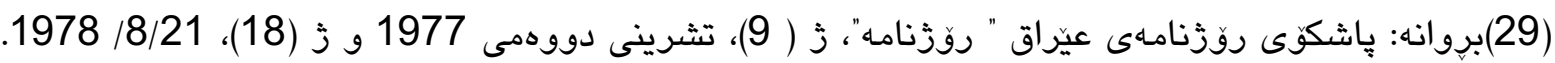

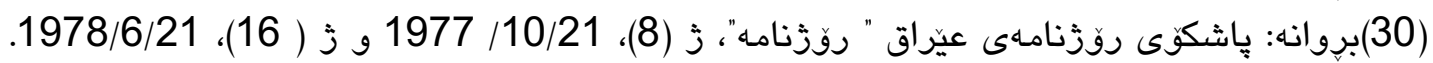

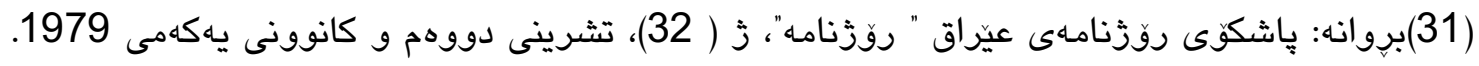




\title{
Mumtaz Haidari and his role in Kurdish Newspaper
}

\section{Barzan Mohammad Ali}

Department of History, College of Art, University of Salahaddin - Erbil ,Kurdistan Region,Iraq. E-mail: barzan.ali@su.edu.krd

\section{Karwan Jawhar Mohammad}

Department of History, College of Art, University of Salahaddin - Erbil ,Kurdistan Region,Iraq. E-mail: karwan.mohammad@su.edu.krd

\begin{abstract}
:
In general this Research paper examines the biography and personality of Mumtaz Haidari and his role in the history of Kurdish newspapers. All the aspects of the study are supported by proofs, evidence from different trusted sources.

The paper expresses its point of views in a very objective way. In all its arguments the writer supports his views and opinions by different sources, in a genuine attempt of him to present a very clear picture of Mr Haidari in all historical incidents of Kurdish history.
\end{abstract}

The research consists of two sections:

The first section sheds light on the life of Mr Haidari. The way he grow up and his works up to the present time.

The second section focuses on his role in Kurdish newspepars and all his activities and contributions to this fiend.

Key Words: Newspaper, Mumtaz, Article, Important, Magazin. 


\section{[مستاز حيدري ودوره في صهيفة كردية}

قسم التاريخ، كلية الفنون، جامعة صلاح الدين - أربيل، إقليم كردستان، العراق.

barzan.ali@su.edu.krd

قسم التاريخ، كلية الفنون، جامعة صلاح الدين - أربيل، إقليم كردستان، العراق.

karwan.mohammad@su.edu.krd

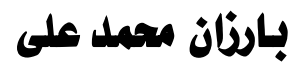

ئيمهيل:

كاروان جوهر محمد نيمل

ئيمهيل:

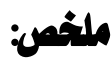

يعتبر ممتاز حيدري من المثقفين المشهرين في مدينة اربيل، وله دور مشهود في هذا المجال. من هذا المنطلق خصص له هذا البحث حول دوره في تاريخ الصحافة الكردية.اهمية هذا البحث تكمن في ان الباحث تناول الاحداث بأمانة علمية وعدم الولوج في دوامة الايديولوجيا. وقد عبر عن رأية في كثير من الاماكن التي استوجبت ذالك. ولهذا عرج علي مصادر متنوعة مختلفة، وبصورتة عامة حاول الباحث ان يعرض دور الحيدري بالوثائق والادلة المطلوبة.

يتكون البحث من محوريين، في المحور الاول تناول أصل الاسرة و حياة الحيدري و مراحل تكوين شخصيته، والمحور الثاني يبحث في دور الحيدري في الصحافة الكوردية بشقيه السري والعلني. لم يواجه الباحث اية مشاكل تستوجب ذكر عدا وجود كثرة المواد والمصادر حول الموضوع بحيث يربك الباحث في استخدامها!، وقد استند الباحث بجملة المصادر القيمة تخص الموضوع.

كلمات الابتماحية : صحيفة، ممتاز، مقالة، هامة، جريلدة. 


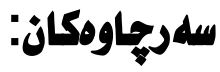

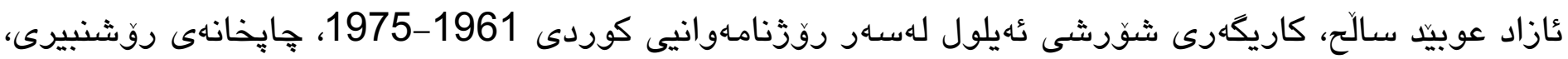
هـاوليز، 2007.

بورهان حاتم كُومهتالّى، سالح حهيدهرى 1922-2001 رِوّلى سياسيى و رووناكبيرى،جَ 1،هـو ليّر، 2012. سهروهر عبدالرحمن عمر، حزبى شيوعى عيّراق و مهسهلهى كورد (1934 - 1975)، جإِخانهى كارو، سليمانى، .2019

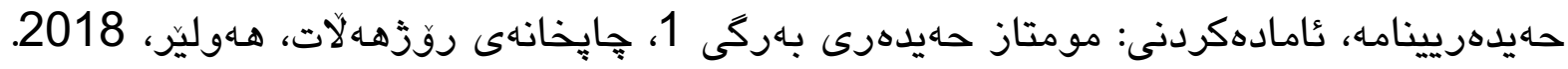

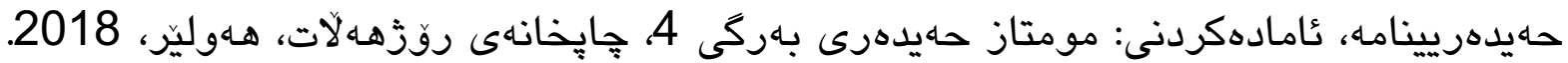
عبدالكريمى مدرس، بنهمالّهى زانياران،ج 1، بهغداد، 1984.

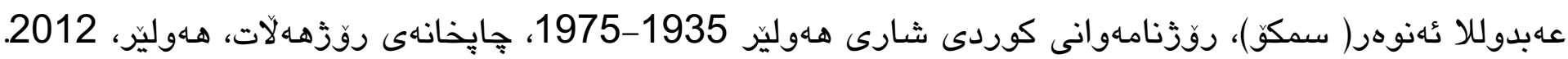
قارهمان حهيدهر عبدالرحمان، بزوتنهوهى روشنبيرى كوردى له شارى هـوليّر 1975-1991، جإخانهى روزَههلات، هـوليز، 2016.

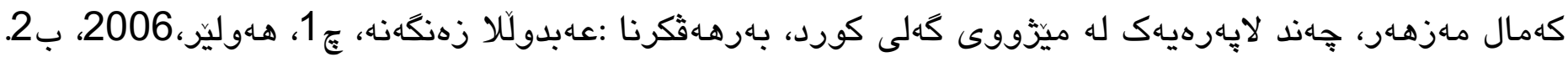

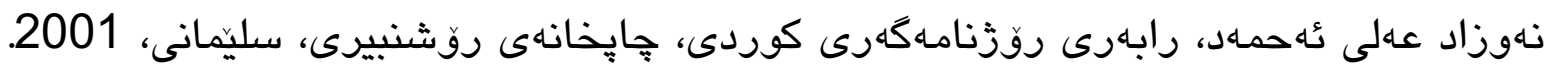
محهمهد عهلى قهردداغى، بووزانهوهى زانايانى كورد له ريكّهى دهستخهتهانيانهوه، ع1، هـوليزر، 2004، ب6. مستهفا نهريمان، بيبلوَكرافياى رِوّنامـى هاوكارى، بهشى يهكهم 1970-1974، جإِخانهى دار الحريه، بهغدا، 1989. 
ياسين قادر بهارزنجى و نهاوزاد على ئهماهد، بييلوكَرافياى ههردوو كوّثارى نووسهارى كورد و نووسهارى كوردستان،

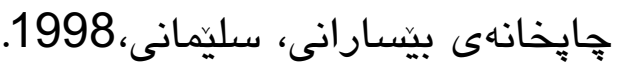

ابراهيم فصيح صبغه الله بن اسعد الحيدرى البغدادي، عنوان المجد فى بيان احوال بغداد والبصره و نجد، تحقيق: كوركيس عواد و ياسين باش اعيان، بيروت، 1999.

ثمينه ناجى يوسف و نزار خالد، سلام عادل "سيره مناضل"،ج 1-2، دمشق، 2001. جمال بابان، أعلام الكرد،ج2، ط2، مطبعة اراس، اربيل، 2012. عبدالرزاق الحسنى، تاريخ الوزارات العراقيه، ط(7)، دار الثوّون الثقافية العامة، بغداد، 1998،ج.

د.على كريم سعيد، عراق 8 شباط 1963 من حوار المفاهيم الى حوار الدم " مراجعات فى ذاكرة طالب شبيب" ط3، بغداد، 2005.

عبدالفتاح على البوتاني، العراق دراسة فى تطورات السياسة الداخلية 14 تموز 1958- 8 شباط 1963،ط1، دمشق، .2008

عصام الدين بن على بن مراد العمري، الروض النضر فى ترجمة ادباء العصر، تحقيق: د. سليم النعيمي، بغداد، 1975، . 3

محمد سعيد الراوى البغدادي، تاريخ الأسر العلمية فى بغداد، تحقيق و تعليق: د. عماد عبدالسلام رؤوف، ط2، بغداد،

محمد امين زكى، مشاهير الكرد و كردستان، ج2، اعداد: رفيق صالح، السليمانية، 2005.

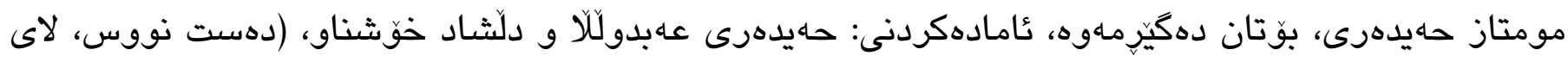
نووسهار پِاريّزراوه). 
مومتاز حهيدهرى، ههوليّز، له (24 / 10 / 2015).

مومتاز حهيدهرى، هـوليّر، له (23/ 6/ 2018).

مومتاز حهيدهرى، هـوليّر، له ( 2018/7/11) .

جهميد حهيدهرى(دكتور)، هـولئ ، له (2015/11/26) .

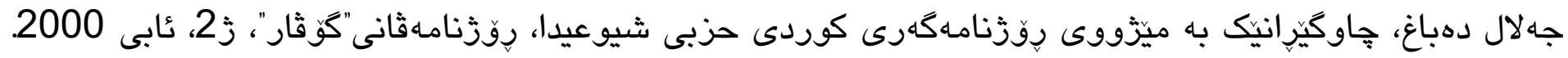
جهمشيد حهيدهرى، فهزيله وهلى جهلهبى 1898-1893، كَّثار " شاووشكا "، ذ (6). مومتاز حهيدهرى، قهلّهم نزيكترين هاوريّمه، يادهوهرى: روّزنامه " عاسوّ "، ذ (1537)، دووشهممه 2011/8/22.

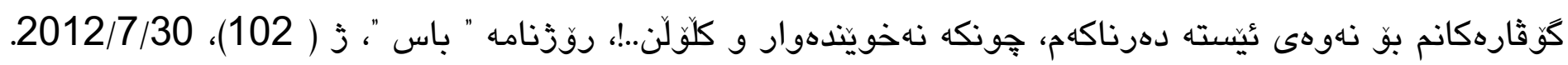

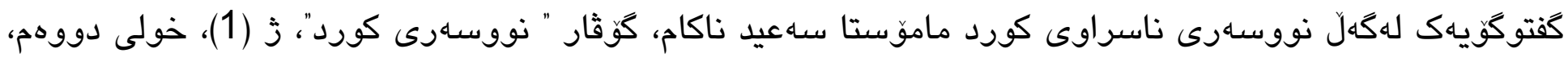
ئايارى 1979.

له دانيشتيكيك دا لهكهل (خاليد دلير)ى شـاعير و هونهرمهند، كَّثار " نووسهارى كورد"، ذ (9)، خولى دووهم، تشرينى دووهدى 1982. ماموّستا سهادى خهرمان بهرهكه، كوّثار " نووسهرى كورد"، ذّ (12)، خولى دووهم، ئابى 1983. له مروّثه روّشنبيره نيشتمانبهروهكانمان: عهبدولَّا عهزيز، كُوثار " نووسهارى كورد"، ذ (7)، خولى دووهم، تهمووزى 


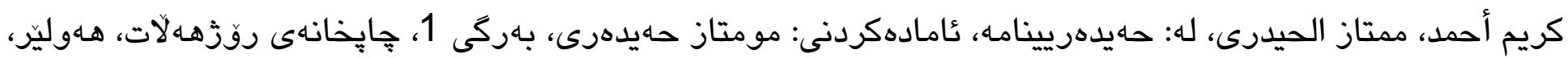
2018

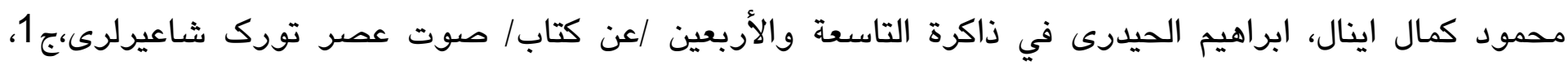

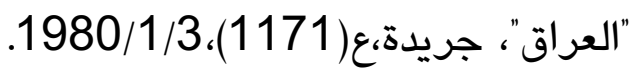

نووسـرى نوكَّ" كَّثار"، ذ (1)، جايخانهى (اسعد)، بغداد، حوزهيرانى 1972. نووسـرى نوكَّ" كَّثار"، ذ (3)، جايخانهى (اسعد)، بغداد، حوزهيرانى 1978.

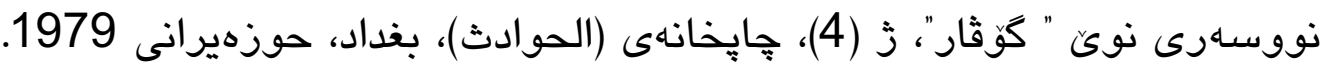
نووسهرى نوكَ" كُوثار"، ذ (5)، جايخانهى (الحوادث)،بغداد، ئهيلولى 1980. كُّثار " نووسهارى كورد"، ذّ (1)، سالّى يهكهم، مارتى 1971. كُّثار " نووسهارى كورد"، ذ (1)، خولى دووهم، ئايارى 1979. كَّثار " نووسهرى كورد"، ذ (2)، خولى دووهم، ئابى 1979. كَّثار " نووسهرى كورد"، ذ (3)، خولى دووهم، مارتى 1980. كُوثار " نووسهرى كورد"، ز (6)، خولى دووهم، شوباتى 1981. كُوثار " نووسهارى كورد"، زماره (12) خولى دووهم، ئابى 1983. هاوكارى " روزّنامه"، ذّ (1)، هـينى 1970/1/9. هاوكارى " روّزنامه"، ذ ( 10)، 20ى مارتى 1970. هاوكارى " روزّنامه"، ذ ( 21)، 6/6/ 1970. 
هاوكارى " روّزنامه"، ذ (24)، 20ى حوزديرانى 1970.

هاوكارى " روّزنامه"، ذ (37)، 11ى تهموزى 1970. هاوكارى " دوزّنامه"، ذ (23)، 10ى تهموزى1971. هاوكارى " روّزنامه"، ذّ (33)، 18ى ئهيلولى 1971. هاوكارى " روزّنامه"، ذ (133)، 9/9/ 1972. هاوكارى " دوّزنامه"، ذُ (137)، 10/7/ 1972. هاوكارى " دوّزنامه"، زٌ (148)، 29/ 12/ 1973. هاوكارى " روّزنامه"، ذ (157)، 3/9/ 1973. هاوكارى " روّزنامه"، ذ (174)، 1973/7/6. هاوكارى " دوزّنامه"، ذُ (179)، 3/10/ 1973. هاوكارى " دوزّنامه"، ذُ (192)، 11/9/ 1973. هاوكارى " روّزنامه"، ذّ (196)، 1973. عيّراق " روّذنامه"، ذ (1)، 11//9/ 1976. عيّراق " دوّذنامه"، ذ (1)، 1977/3/21. بِاشكوى روّزنامهى عيّراق " روّزنامه"، ذ (2)، 11/23/ 1976. بِاشكوى روّزنامهى عيّراق " روّزنامه"، ذ (8)، 10/21/ 1977. پاشكوى روّزنامهى عيّراق " دوّذنامه"، ذ ( 9)، تشرينى دووهمى 1977. 


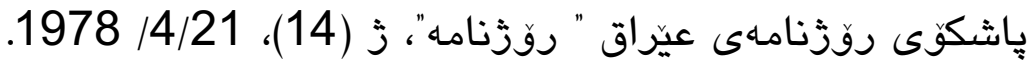

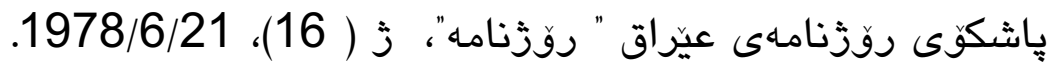

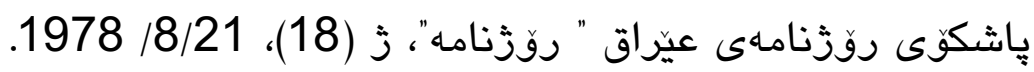

$$
\begin{aligned}
& \text { پِاشكوى روّزنامهى عيّراق " روّزنامه"، ذّ ( 32)، تشرينى دووهم و كانوونى يهكهمى } 1979 . \\
& \text { روّنبير " كَوْار"، ذ (1)، } 1973 . \\
& \text { كُثار " K21"، ز (5-6)، } 2009 .
\end{aligned}
$$

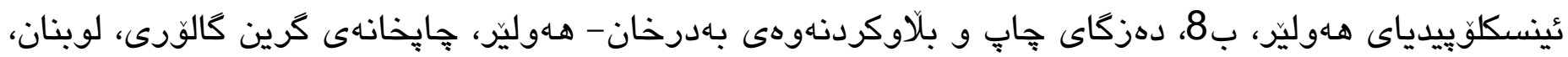

